\title{
C-type natriuretic peptide regulates endochondral bone growth through p38 MAP kinase-dependent and - independent pathways Hanga Agoston ${ }^{1}$, Sameena Khan ${ }^{1}$, Claudine G James ${ }^{1}$, J Ryan Gillespie ${ }^{1}$, Rosa Serra $^{2}$, Lee-Anne Stanton ${ }^{1}$ and Frank Beier*1
}

\begin{abstract}
Address: ${ }^{1}$ CIHR Group in Skeletal Development and Remodeling, Department of Physiology and Pharmacology, University of Western Ontario, London, ON, N6A 5C1, Canada and 2Department of Cell Biology, University of Alabama, Birmingham, USA

Email: Hanga Agoston - hagosto@uwo.ca; Sameena Khan - sameena_khan4@hotmail.com; Claudine G James - claudine.james@fmd.uwo.ca; J Ryan Gillespie - ryan.gillespie@fmd.uwo.ca; Rosa Serra - Rserra@uab.edu; Lee-Anne Stanton - lstanton@uwo.ca; Frank Beier* - fbeier@uwo.ca

* Corresponding author
\end{abstract}

Published: 20 March 2007

BMC Developmental Biology 2007, 7:18 doi:10.1186/147|-2/3X-7-18
Received: 4 August 2006

Accepted: 20 March 2007

This article is available from: http://www.biomedcentral.com/147/-2/3X/7//8

(c) 2007 Agoston et al; licensee BioMed Central Ltd.

This is an Open Access article distributed under the terms of the Creative Commons Attribution License (http://creativecommons.org/licenses/by/2.0), which permits unrestricted use, distribution, and reproduction in any medium, provided the original work is properly cited.

\begin{abstract}
Background: C-type natriuretic peptide (CNP) has recently been identified as an important anabolic regulator of endochondral bone growth, but the molecular mechanisms mediating its effects are not completely understood.

Results: We demonstrate in a tibia organ culture system that pharmacological inhibition of p38 blocks the anabolic effects of CNP. We further show that CNP stimulates endochondral bone growth largely through expansion of the hypertrophic zone of the growth plate, while delaying mineralization. Both effects are reversed by p38 inhibition. We also performed Affymetrix microarray analyses on micro-dissected tibiae to identify CNP target genes. These studies confirmed that hypertrophic chondrocytes are the main targets of CNP signaling in the growth plate, since many more genes were regulated by CNP in this zone than in the others. While CNP receptors are expressed at similar levels in all three zones, cGMP-dependent kinases I and II, important transducers of CNP signaling, are expressed at much higher levels in hypertrophic cells than in other areas of the tibia, providing a potential explanation for the spatial distribution of CNP effects. In addition, our data show that CNP induces the expression of NPR3, a decoy receptor for natriuretic peptides, suggesting the existence of a feedback loop to limit CNP signaling. Finally, detailed analyses of our microarray data showed that CNP regulates numerous genes involved in BMP signaling and cell adhesion.
\end{abstract}

Conclusion: Our data identify novel target genes of CNP and demonstrate that the p38 pathway is a novel, essential mediator of CNP effects on endochondral bone growth, with potential implications for understanding and treatment of numerous skeletal diseases.

\section{Background}

Bone formation occurs through the related, but distinct processes of intramembranous and endochondral ossification $[1,2]$. While the former is responsible for the for- mation of bones directly from precursor cells, such as the majority of the skull, the latter is responsible for the development of long bones, ribs, and vertebrae through a cartilage intermediate. In endochondral ossification, 
mesenchymal cells condense and begin to differentiate into chondrocytes, some of which later form the growth plate that controls longitudinal growth of endochondral bones [3]. The growth plate zones consists of resting, proliferating, and terminally differentiated hypertrophic chondrocytes, each of which are characterized by the expression of specific markers $[4,5]$. This organization of the growth plate and the coordinated proliferation and hypertrophy of chondrocytes are responsible for elongation of bones and eventually determine final bone length. Hypertrophic chondrocytes are thought to undergo apoptosis, and simultaneously their surrounding cartilaginous matrix is degraded and replaced by bony tissue, produced by cells entering through vascularization of hypertrophic cartilage. The intricate control mechanisms regulating the proliferation, differentiation and apoptosis of chondrocytes as well as the subsequent vascular invasion are not completely understood. However, disturbances of these processes can result in numerous diseases such as chondrodysplasias and other growth disorders, demonstrating the need for a better understanding of the pathways involved [4,6-9].

C-type natriuretic peptide (CNP) has recently been shown to be an important regulator of endochondral ossification. The dominant phenotype of CNP-deficient mice is dwarfism, as demonstrated by shortened long bones primarily due to reduced heights of proliferating and hypertrophic zones of the growth plate $[10,11]$. CNP also increases growth in mouse bone organ cultures $[12,13]$. More recently, loss-of-function mutations in NPR2, the gene encoding the CNP receptor, have been identified as cause of acromesomelic dysplasia type Maroteaux, an autosomal recessive chondrodysplasia in humans [14]. This CNP receptor is also known as guanylyl cyclase- $\mathrm{B}$ (GC-B) or NPR-B. Binding of CNP to GC-B results in increased intracellular cGMP, which can further activate downstream factors, such as cGKI and cGKII (cGMPdependent protein kinase I and II) as well as phosphodiesterases (PDEs) that break down cGMP and camp and specific ion channels [15-18]. In addition, CNP can also bind to a different receptor, NPR-3 (natriuretic peptide receptor 3) that is thought to act as a decoy/clearance receptor serving to limit the effects of natriuretic peptides. Interestingly, mice deficient for cGKII show a similar, although not identical phenotype to CNP-deficient mice [19], and cGKII has been shown to be required for the effects of CNP overexpression in transgenic mice [20]. These data clearly identify cGKII as an essential mediator of CNP effects, but the signaling pathways downstream of cGKII, potential parallel pathways and the target genes conferring cartilage responses to CNP are not completely understood. However, recent studies showed that overexpression of CNP results in inhibition of the MEK1/2ERK1/2 MAP kinase pathway and rescues the effects of an activating fibroblast growth factor receptor 3 mutation on endochondral bone growth [21-23].

MAP kinases are central signaling molecules in most eukaryotic cells that integrate extracellular signals leading to altered cell proliferation, differentiation, and transcription in many cell types, including chondrocytes $[24,25]$. For example, both the ERK and the p38 MAPK families have been shown to play important roles in controlling chondrocyte differentiation in vitro and in vivo $[3,26,27]$. In the current study we demonstrate, for the first time, an essential role for the p38 MAP kinase pathway in CNP signaling in cartilage and identify target genes of CNP in chondrocytes using genome-wide microarrays.

\section{Results \\ CNP signaling enhances endochondral bone growth}

We used an organ culture system of embryonic day 15.5 (E15.5) mouse tibiae to examine the effects of CNP on endochondral bone growth. Tibiae were cultured for six days in the presence of BSA (control) or different concentrations of CNP. $10^{-8}, 10^{-7}$ and $10^{-6} \mathrm{M}$ concentrations of CNP caused a $31 \%, 40 \%$, and $42 \%$ increase, respectively, in longitudinal growth of tibiae (Fig. 1A,B). Treatment with $1 \mu \mathrm{M}$ CNP almost doubled tibia weight relative to controls (Fig. 1C). Incubation of tibiae with $10^{-4} \mathrm{M}$ (8-(4chlorophenylthio) cGMP stimulated tibia growth in a similar or stronger manner (55\%) as CNP (Fig. 1D). A general inhibitor of phosphodiesterases (PDEs), 3-Isobutyl-1-methylxanthine (IBMX) at $10^{-4} \mathrm{M}$, was used to study the role of PDEs in bone growth in the organ cultures. PDE inhibition stimulated longitudinal growth by $30 \%$ when compared to the control. In contrast, specific inhibition of PDE 1 by 8-methoxymethyl IBMX did not alter bone growth significantly, indicating that this enzyme is either not involved in regulating bone growth or can be functionally replaced by other proteins. These data demonstrate that $\mathrm{CNP} / \mathrm{cGMP}$ signaling stimulates endochondral bone growth, while PDEs inhibit this process. Removal of the perichondrium by enzymatic digestion and/or manual dissection did not alter the response to $\mathrm{CNP}$, demonstrating that the anabolic effects of CNP are independent of the perichondrium (Fig. 1E).

At the histological level, the most significant effect of CNP was a marked expansion of the hypertrophic zone (Fig. 2A). This enlargement of the hypertrophic zone was accomplished by increases in both the number and maximal size of hypertrophic chondrocytes (Fig. 2B), in agreement with earlier studies [23].

\section{CNP-induced endochondral bone growth requires $p 38$ MAP kinase signaling}

MAP kinases play multiple roles in chondrocyte differentiation and cartilage development [3]. We therefore exam- 

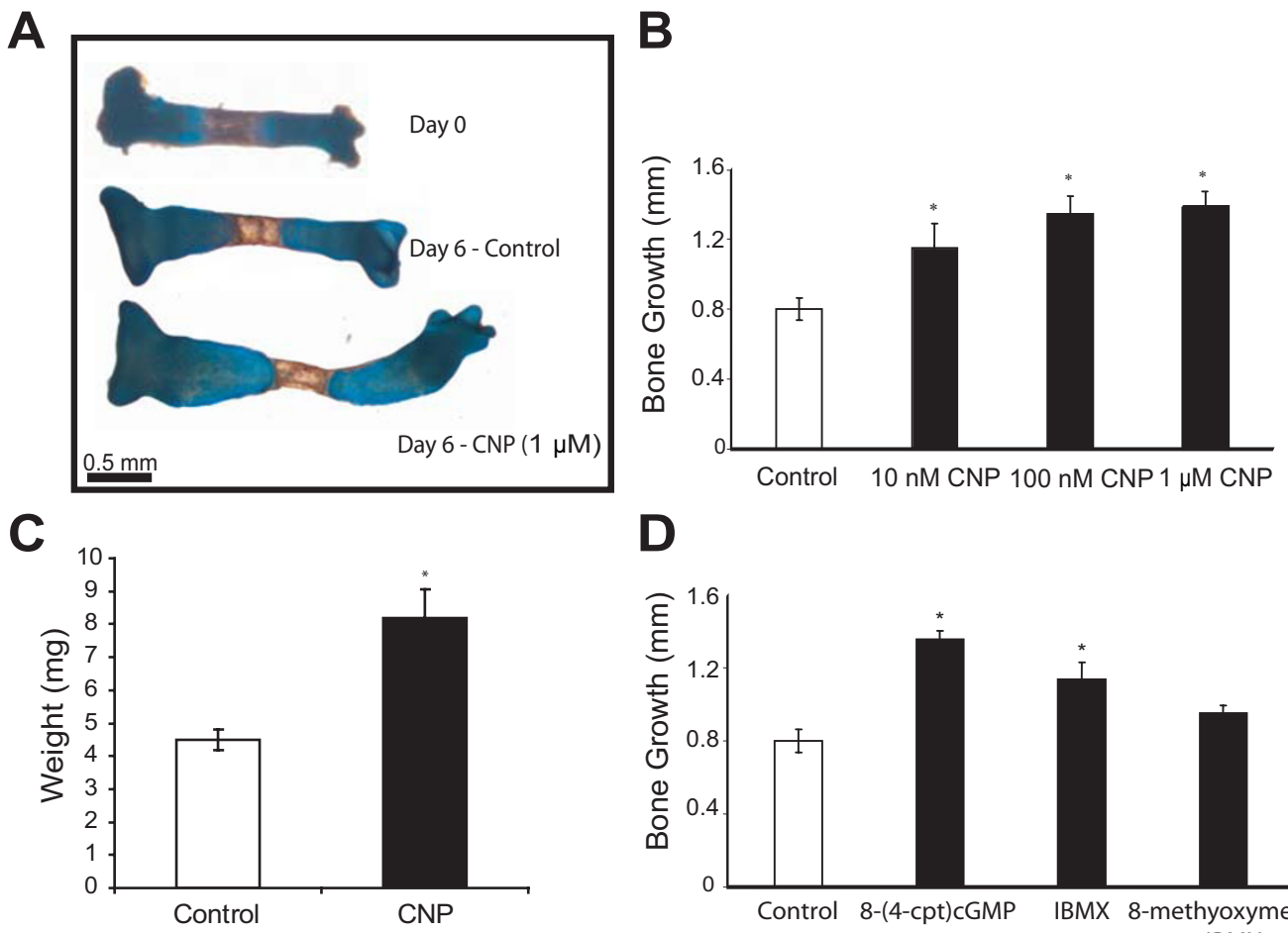

D

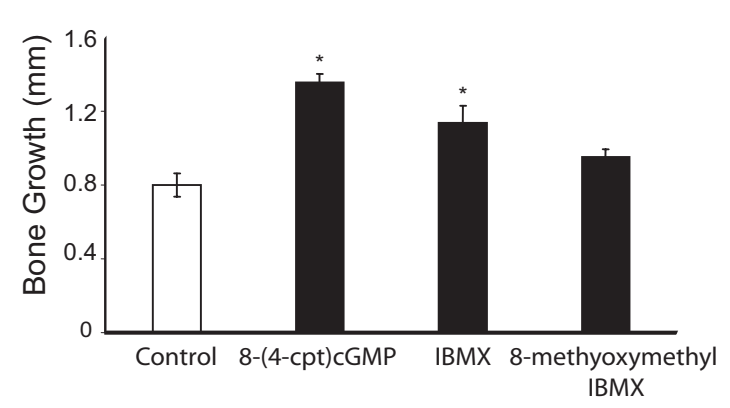

$\mathbf{E}$

Intact Perichondrium Remove Perichondrium Remove Perichondrium

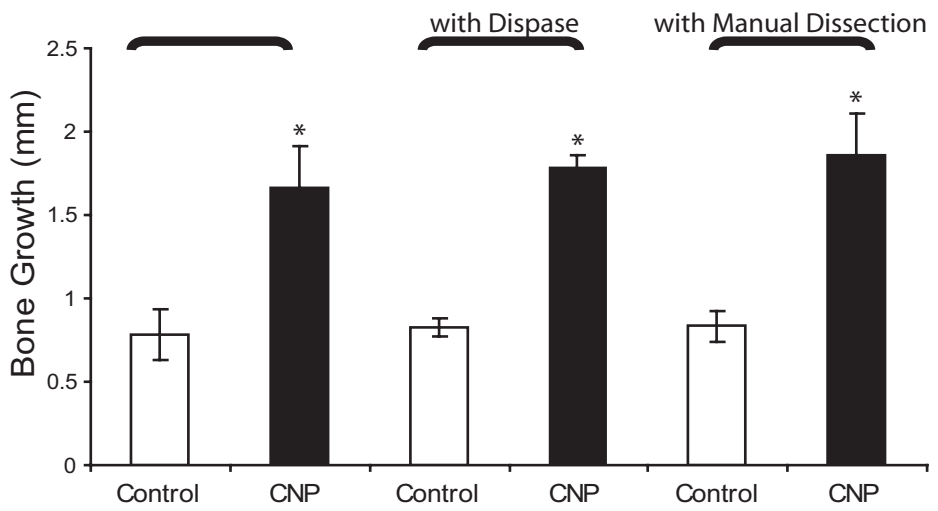

Figure I

CNP enhances endochondral bone growth. Mouse EI5.5 tibiae were harvested and cultured for six days in the presence of vehicle, CNP at the indicated concentrations, membrane-permeable 8-(4-cpt) cGMP (0.I mM), the non-specific PDE inhibitor IBMX (0.I mM), or a selective inhibitor of PDE I, 8-methooxymethyl, IBMX (I0 $\mu \mathrm{M})$. After six days in culture, vehicle and CNP-treated $(I \mu M)$ bones were stained with Alcian Blue and Alizarin Red and representative images are shown, in comparison to a freshly isolated tibia (A). Growth of tibiae over the culture period at indicated concentrations of CNP and treatments was measured (B, D), and the weight of bones was determined (C). CNP, 8-(4-cPt) cGMP and IBMX stimulated tibia growth, when compared to control conditions. EI5.5 tibiae were isolated under three different conditions: perichondrium was left intact with very loose dissection, perichondrium was removed with dispase, and perichondrium was removed mechanically (E). Bones were then incubated with or without CNP $(I \mu M)$ for six days and bone growth was determined as change in bone length relative to day I. Removal of the perichondrium did not influence the stimulatory effect of CNP on bone growth. All data represent means $\pm S D$ of three or four independent trials $(p<0.05)$. 
A
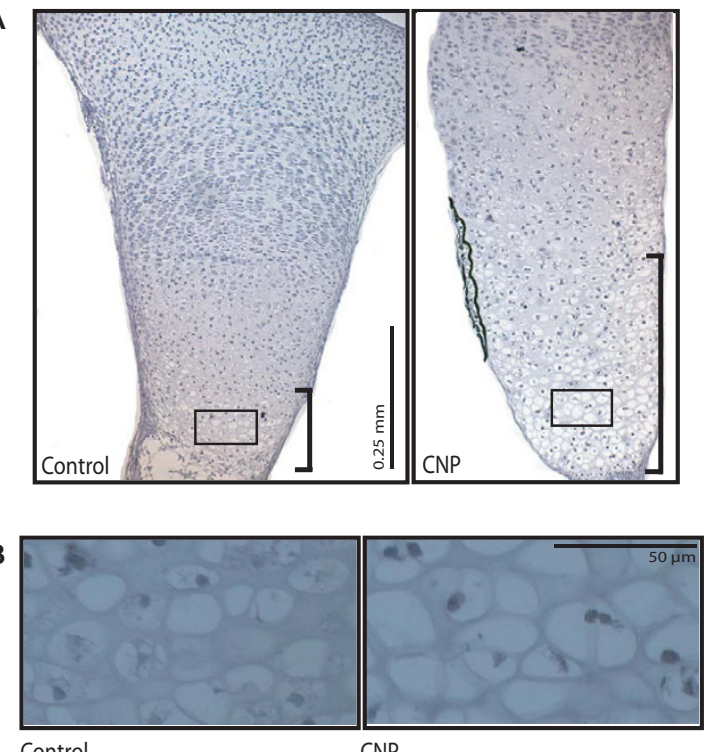

Figure 2

CNP induces expansion of the hypertrophic zone. Hematoxylin and Eosin staining of tibia sections after six days of culture with or without CNP $(I \mu M)$ showed differences in growth plate architecture, primarily in the hypertrophic zone. CNP treatment results in a vastly expanded hypertrophic zone (A; hypertrophic zones indicated by brackets). Magnification of cells in the hypertrophic zone (boxes from A) shows that individual chondrocytes are larger in CNPtreated tibiae (B).

ined a potential role of the MEK (MAP/ERK kinase) 1/2ERK1/2 and p38 cascades in CNP-induced endochondral bone growth. In the absence of exogenous CNP, the pharmacological MEK1/2 inhibitors PD98059 and U0126 (10 $\mu \mathrm{M}$ each) stimulated tibia growth by $39 \%$ and $30 \%$, respectively (Fig. 3A). While simultaneous addition of MEK inhibitors and CNP had maximal effects on bone growth, these effects were not statistically different from treatment with CNP alone. These data suggest that CNP and MEK1/2 act through a common pathway and are in agreement with recent studies demonstrating an inhibitory role of the MEK/ERK cascade in endochondral bone growth [26] and down-regulation of MEK/ERK activity by CNP [21-23].

We next examined whether $\mathrm{p} 38$ is involved in the effects of CNP on cartilage growth. Inhibition of p38 activity by two different compounds, PD169316 or SB202190 (10 $\mu \mathrm{M}$ each), did not affect basal endochondral bone growth, when compared to the inactive control compound SB202474 $(10 \mu \mathrm{M})$ (Fig. 3B). In contrast, inhibition of p38 by SB202190 or PD169316 blocked CNP-induced growth (Fig. 3B). This effect was obvious by day 6 of culture and maintained by day 8 (Fig. 3C). Moreover, p38 inhibition completely reversed CNP effects on tibia weight (Fig. 3D), further demonstrating a requirement for p38 activity in CNP-induced endochondral bone growth. Next we examined whether CNP regulates the p38 pathway by investigating the phosphorylation of the kinases MKK3 (MAP kinase kinase3) and MKK6, direct and specific activators of $\mathrm{p} 38$. Western blotting with phosphospecific antibodies revealed that CNP and cGMP increase the phosphorylation of MKK3/6 in primary chondrocytes after 10 minutes of incubation (Fig. 3E), demonstrating that CNP signaling activates the $\mathrm{p} 38$ pathway in chondrocytes. Immunohistochemistry for phosphorylated (active) p38 showed little staining under control conditions, but demosntrated a strong increase in $\mathrm{p} 38$ phosphorylation in CNP-treated tibiae (Fig. 3F).

\section{CNP delays tibia mineralization in a p38-dependent} manner

To examine the effects of $\mathrm{p} 38$ inhibition on growth plate organization, we performed histological analyses of organ culture sections. As above, CNP stimulation caused an expansion of the hypertrophic zone of the growth plate, while SB202190 by itself did not have any marked effects (Fig. 4A). However, p38 inhibition suppressed the enlargement of the hypertrophic zone in response to $\mathrm{CNP}$, providing further evidence for a requirement for p38 activity for the anabolic effects of CNP.

During dissections and analyses of organ cultures, we also noticed that CNP-treated bones were more fragile and appeared less mineralized. Alcian Blue/Alizarin Red staining of tibiae confirmed that the mineralized area was smaller in CNP-treated bones and displayed weaker Alizarin Red staining (Fig. 4B). We quantified the area of the mineralized (red) and cartilaginous (blue) regions of tibiae using digital image analyses. CNP treatment did increase the Alcian Blue-stained area considerably, without effects on the Alizarin Red-stained area (Fig. 4C). This resulted in a reduction of the mineralized area relative to the total area of the bone by about $30 \%$. These data suggests that CNP-induced growth of cartilage is not matched by a corresponding expansion of the mineralized area and that CNP treatment delays the remodeling of hypertrophic cartilage. Inhibition of p38 activity by SB202190 resulted in a slight, but significant increase of the mineralized area (relative to total area) and reversed the effects of $\mathrm{CNP}$ on the Alcian Blue-stained area completely (Fig. 4C).

\section{Microarray analyses identify hypertrophic chondrocytes as main targets of CNP signaling}

We next performed microarray analyses to identify target genes of CNP in chondrocytes. Tibiae were cultured for six days in the absence or presence of CNP and then micro- 
dissected into three distinct zones: the resting/proliferative (RP), the hypertrophic $(\mathrm{H})$, and the mineralized $(\mathrm{M})$ zones (Fig. 5A). RNA was isolated directly from tibiae from three independent trials for each zone and both treatments were analyzed using Affymetrix Mouse 2.0 arrays in the London Regional Genomics Center as described (London, Ontario, Canada) [28]. Real-time PCR analyses of collagen II (Col2a1) and collagen X (Col10a1), known markers of cartilage development, confirmed that micro-dissection resulted in efficient separation of the zones (Fig. 5B). Microarray profiles of selected genes involved in endochondral bone growth are shown to further illustrate correct separation of zones (Fig. 5C).

Bioinformatics analyses of microarray results (Fig. 6A) demonstrated that the hypertrophic zone was most responsive to CNP (Fig. 6B). Only 47 probe sets in the resting/proliferative zone ( 35 down, 12 up) and 58 probe sets in the mineralized zone ( 41 down, $17 \mathrm{up}$ ) responded with minimum two-fold responses to CNP (see Table 1 and 2 for lists of regulated genes). In contrast, 309 probe sets in the hypertrophic area showed a two-fold or higher change in expression in response to CNP. Of these probe sets, 157 probe sets were up-regulated by CNP in the hypertrophic zone, and 152 were down-regulated by CNP (Table 3).

One of the genes showing a strong increase in the hypertrophic zone ( $>6$-fold) was Ptgs 2 , encoding cyclooxygenase 2 (Cox2), a key enzyme in the synthesis of prostaglandins. Since Ptgs2 and its products (such as prostaglandin E2) are known to play important roles in chondrocyte differentiation and skeletal remodeling [2931 , we selected this gene for validation experiments. Induction of Cox 2 mRNA expression in the hypertrophic zone by CNP was confirmed by real-time PCR, which showed a 10-fold increase in transcript levels (Fig. 6C). p38 inhibition did reduce the basal levels of Cox2 mRNA, but surprisingly did not affect the induction by CNP. Among the genes down-regulated by CNP was the Tnfsf 11 gene, encoding RANKL, a known activator of osteoclastic resorption of bone and cartilage [32,33]. Tnfsf11 displayed a 3.8-fold reduction in expression according to microarray analyses. Because down-regulation of Tnfsf11 could provide a molecular mechanism for the observed delay in mineralization and cartilage remodeling in response to CNP, we chose to validate its expression. Realtime PCR analysis confirmed down-regulation of Tnfsf 11 mRNA levels in the hypertrophic zone by CNP (Fig 6D).

To answer the question why the hypertrophic zone is much more responsive to CNP treatment than other zones, we examined expression of key genes in the CNP signaling pathway. Analyses of our microarray data demonstrated that the genes encoding CNP $(N p p c)$, its signal- ing receptor GC-B (Npr2) and the decoy receptor (Npr3) are expressed at similar levels in all three zones of microdissected tibiae under control conditions (Fig. 7A). However, Prkg1 (encoding cGMP-dependent kinase I) expression is 5.9 fold higher in hypertrophic chondrocytes than in the resting/proliferative cells, and seven-fold higher in the hypertrophic versus the mineralized zone (Fig. 7A). Similarly, Prkg2 expression is 4.4-fold and 2.5-fold higher in the hypertrophic zone versus the resting/proliferative and mineralized zones, respectively (Fig. 7A). This expression pattern of key mediators of CNP signaling can explain the strong responsiveness of hypertrophic chondrocytes to CNP. In addition, our microarray data on expression of the decoy receptor Npr3 in the hypertrophic zone, while variable and thus not statistically significant, suggested that CNP strongly activates the expression of $N$ pr3. We therefore decided to analyze its expression by real-time PCR which demonstrated a statistically significant 16-fold induction of $\mathrm{Npr} 3$ expression in the hypertrophic zone by CNP that was not altered by p38 inhibition (Fig. 7B). CNP did not affect Npr3 expression in the other growth plate zones.

\section{Annotation of microarray data identifies CNP-regulated pathways}

To gain insight into biological processes regulated by CNP, we employed KEGG annotation [34] on genes showing at least two-fold changes in response to CNP in the hypertrophic area (Fig. 8A). Numerous pathways were affected by CNP, most of them comprised approximately proportionally by up- and down-regulated genes. However, genes related to cell adhesion were strongly enriched in up-regulated genes, suggesting that CNP promotes cell adhesion. Most notably, CNP induced expression of genes involved in cell-cell interactions such as Icam2 (intercellular adhesion molecule 2), Cdh5 (Cadherin 5), and Esam1 (endothelial cell-specific adhesion molecule). In contrast, down-regulated genes included many genes encoding extracellular matrix molecules, for example Matn1 and Matn3 (Matrilin 1 and 3), Col9a2 (procollagen type IX, alpha 2) and Col14a1 (procollagen type XIV, alpha 1) (Table 3 ). In addition, up-regulated genes included three members of the TGF $\beta$ superfamily, Gdf5, Inhbb and Inhba, as well as the BMP antagonist Grem1 (Fig. 8B). Besides the TGF $\beta$ family, members of the Wnt and hedgehog signaling pathways are important regulators of cartilage differentiation, and components of these pathways were regulated by CNP. Other categories in which up-regulated genes were over-represented included tight junctions and calcium signaling, whereas pantothenate and CoA biosynthesis was one example for a pathway dominated by down-regulated genes. Finally, more transcription factorencoding genes were up-regulated than down-regulated by CNP (Fig. 8B). 
A

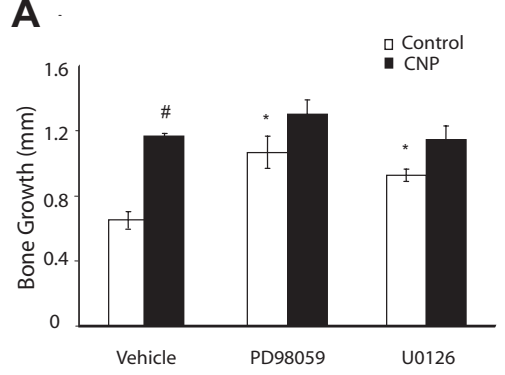

C

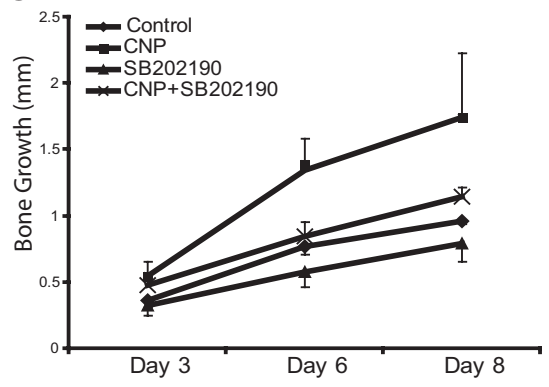

B

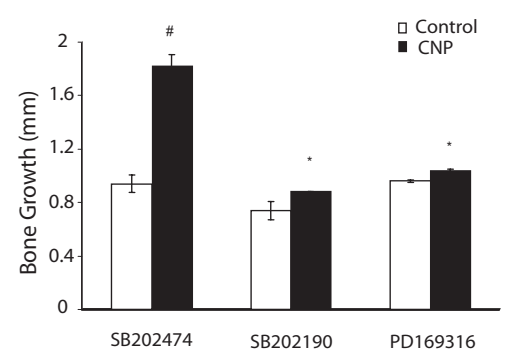

D

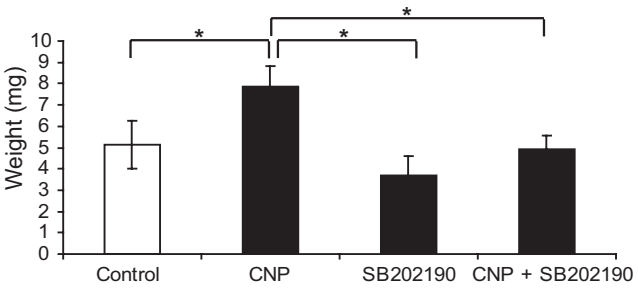

E

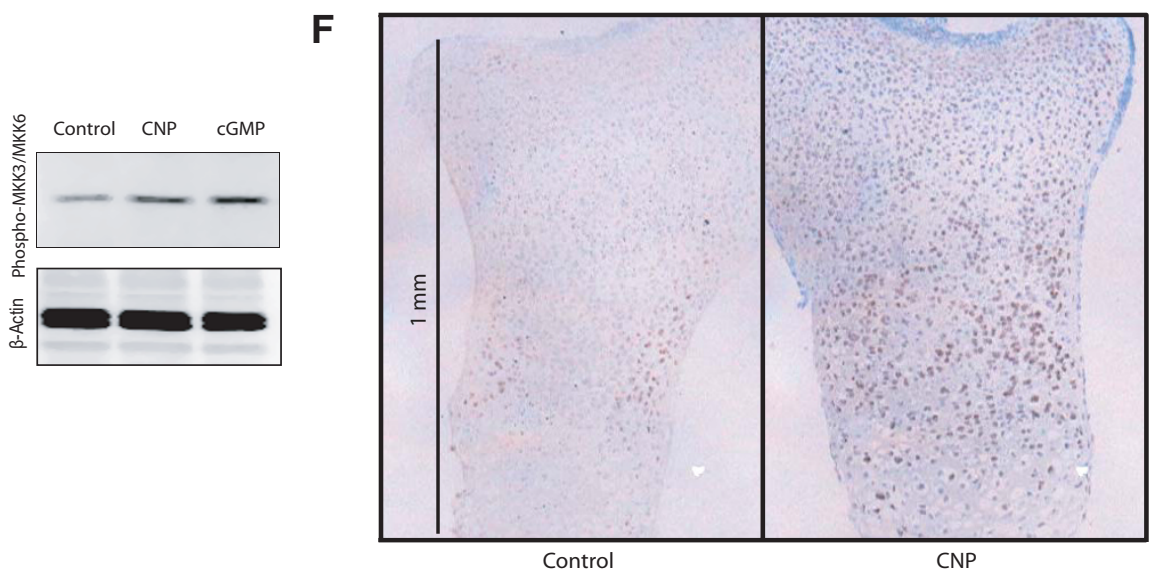

Figure 3

Inhibition of the MEKI/2-ERKI/2 pathway stimulates tibia growth, while p38 MAPK is required for CNP-

induced bone growth. Mouse EI5.5 tibiae were harvested and cultured for six days in the presence of control or CNP (I $\mu \mathrm{M})$ and vehicle (DMSO) or MEKI/2-ERKI/2 pathway inhibitors PD98059 (I0 $\mu \mathrm{M})$ and U0I26 (I0 $\mu \mathrm{M})(\mathbf{A})$. Though both PD98059 and U0I 26 stimulated basal bone growth, inhibition of the MEKI/2-ERKI/2 pathway did not further enhance CNPinduced bone growth $(*: p<0.05$ when comparing control/inhibitors to control/vehicle; \#: $p<0.05$ when comparing CNP/ vehicle to control/vehicle; $p>0.05$ when comparing CNP/vehicle to CNP/inhibitors). Tibiae were incubated with control or CNP and pharmacological inhibitors of the P38 MAPK pathway (SB202190 or PDI69316, $10 \mu \mathrm{M}$ each) or an inactive analog (SB202474, $10 \mu \mathrm{M})(\mathrm{B})$. P38 inhibition did not effect basal bone growth significantly, but did suppress CNP-induced bone growth $(*: \mathrm{p}<0.05$ when comparing CNP/inhibitors to CNP/SB202474; \#: $\mathrm{p}<0.05$ when comparing CNP/SB202474 to control/SB202474). Bone growth was measured over an extended time course of eight days, showing that CNP continued to significantly influence growth on day 8, while SB202190 reversed these effects (C). Bones from each treatment were weighed under different conditions, and it was found that $p 38$ inhibition reversed the effects of CNP on weight (D). Protein extracts from primary chondrocytes cultured with control, CNP $\left(10^{-6} \mathrm{M}\right)$, or 8-(4-cpt) cGMP $(0.1 \mathrm{mM})$ for 10 minutes were examined for phosphorylation of the $\mathrm{p} 38$ activators MKK3/6 by western blot analysis (E). Both treatments increased phosphorylation of MKK3/6, supporting the stimulation of p38 MAP kinase activity by CNP signaling. Immunohistochemistry with an antibody against phosphorylated p38 demonstrates markedly higher signal in CNP-treated tibiae when compared to control bones (F). 


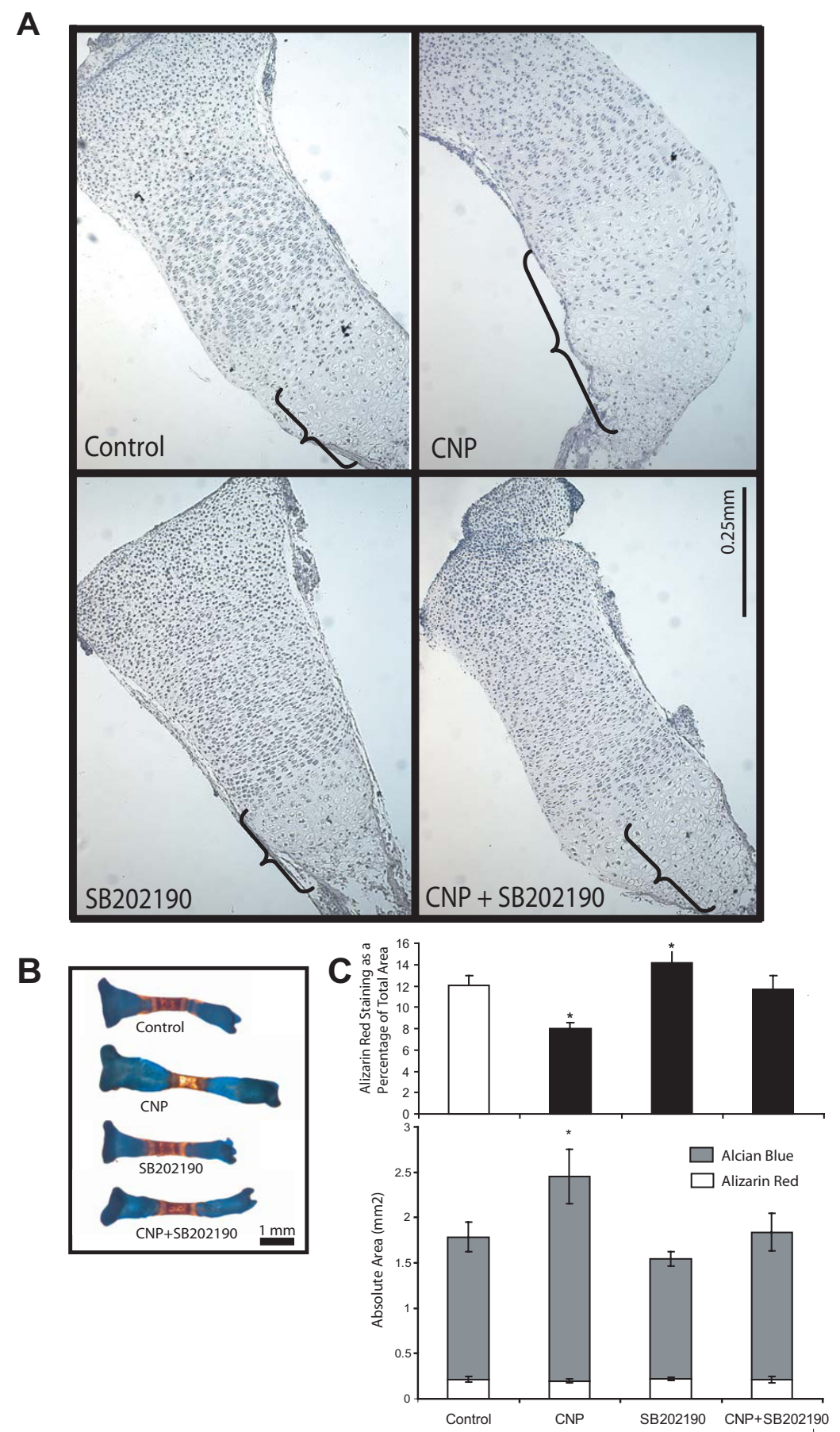

\section{Figure 4}

p38 MAPK activity is required for CNP-induced hypertrophy. EI5.5 tibiae were isolated and incubated with or without CNP (I $\mu \mathrm{M})$ and DMSO or SB202190 (I0 $\mu \mathrm{M})$. Hematoxylin and Eosin staining of tibia sections after six days of culture show that $\mathrm{p} 38$ inhibition reversed CNP-induced expansion of the hypertrophic zone $(\mathbf{A})$. Tibiae were stained with Alizarin Red and Alcian Blue, and representative images demonstrate increased bone growth by CNP and the reversal of these effects upon p38 inhibition (B). The area of the mineralized zone (red) was measured as absolute area (C, bottom) and as a percentage of total area (C, top), demonstrating that CNP-treated bones displayed significantly smaller mineralized area in relation to the whole bone area. This was reversed upon $\mathrm{p} 38$ inhibition. Representative images are shown, while all data represent means \pm SD of four independent trials, each with six bones $(p<0.05)$. 
A

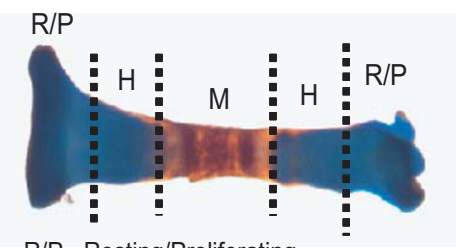

R/P - Resting/Proliferating

$\mathrm{H}$ - Hypertrophic

M - Mineralized

B

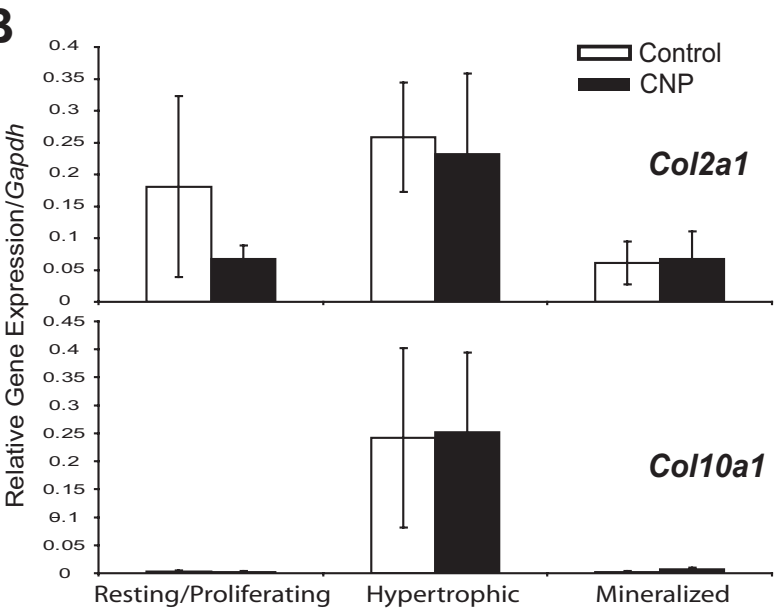

C

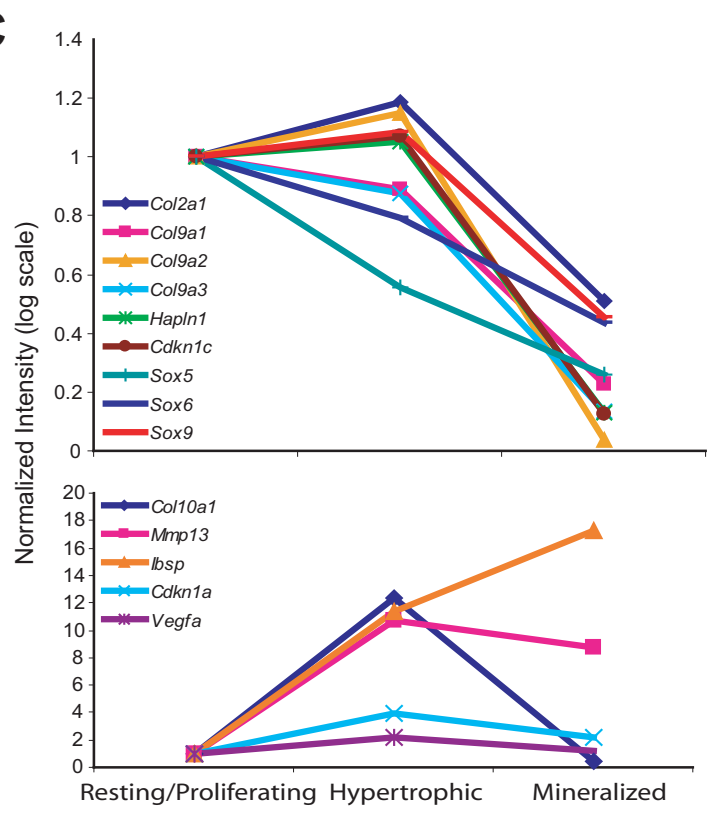

\section{Figure 5}

Micro-dissection efficiently separates different growth plate zones from cultured tibiae. EI5.5 tibiae that were harvested and incubated with or without CNP $(\mathrm{I} \mu \mathrm{M})$ for six days were micro-dissected into the resting/proliferating, hypertrophic, and mineralized regions as shown (A). Zones from approximately 24 bones were pooled together. RNA was isolated directly from micro-dissected tibia and analyzed by microarray as described in Materials and Methods. Real-time PCR analyses confirmed expected expression patterns of the cartilage markers Col2al and Coll Oal in control bones (B; data represent means \pm SD from three independent trials). Expression patterns of selected chondrocyte marker genes under control conditions in our microarray data sets further demonstrated efficient separation of regions (C). 


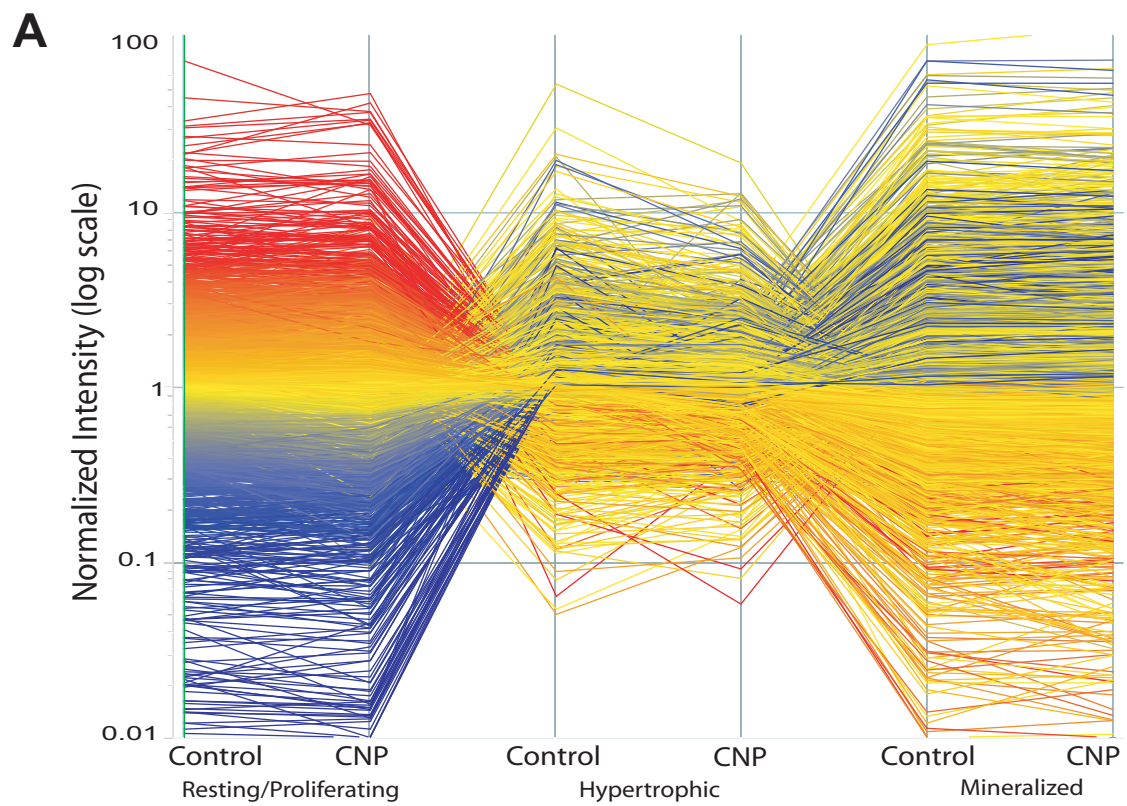

B
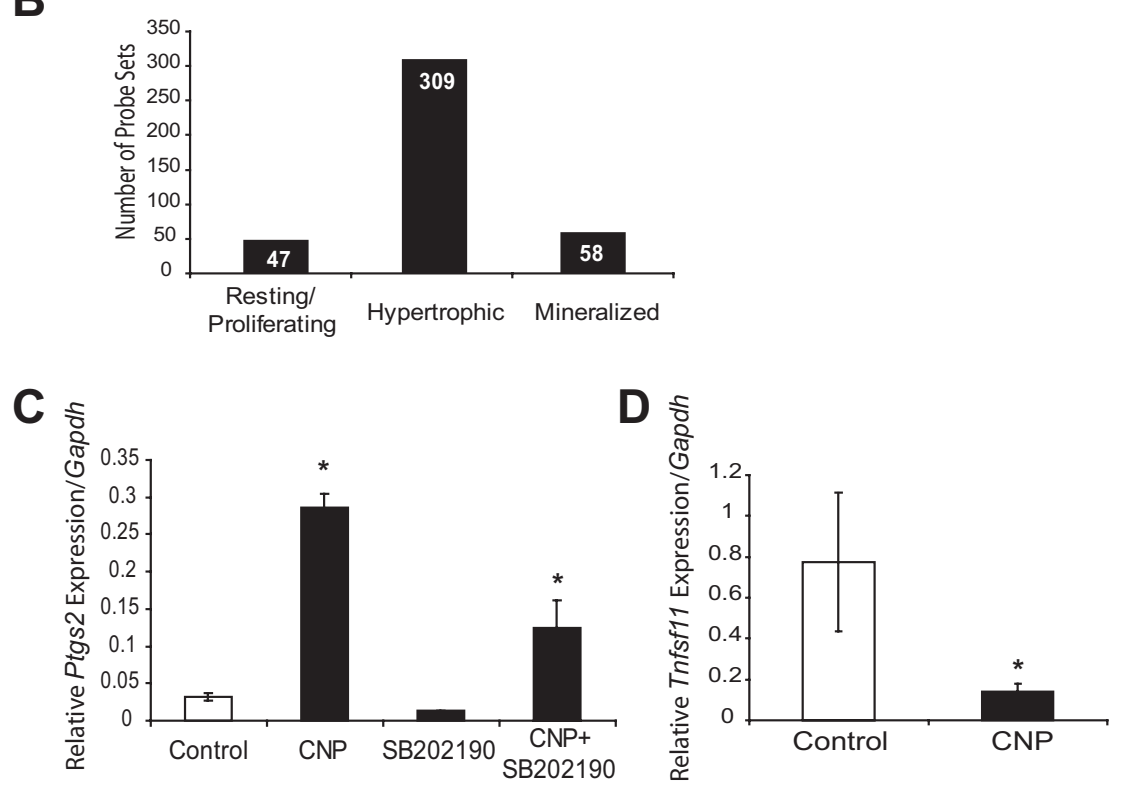

\section{Figure 6}

Microarray analyses identify the hypertrophic area as the main target of CNP treatment. EI5.5 tibiae were isolated, incubated with or without CNP (I $\mu \mathrm{M})$ and DMSO or SB202 I90 (I0 $\mu \mathrm{M})$ and micro-dissected into the resting/proliferating, hypertrophic, and mineralized regions prior to RNA extraction and microarray analyses. Analyses of microarray results from three independent trials using Genespring 7.2 (A) illustrated that the hypertrophic zone was most significantly responsive to CNP treatment, when compared to control conditions (B). Six times as many probe sets showed at least 2-fold expression changes in the hypertrophic zone when compared to either resting/proliferating or mineralized regions. Real-time PCR analyses on micro-dissected tibiae were used to validate selected microarray patterns. CNP induction of Ptgs2, the gene encoding cyclooxygenase-2, was confirmed (C). SB202190 treatment did reduce basal Cox2 mRNA levels, but did not interfere with CNP induction of Cox2. Tnfsfl I, the gene encoding RANKL, was confirmed to be down-regulated in response to CNP treatment. Data represent means \pm SD of three independent trials $(p<0.05)$. 
Table I: Genes showing 2-fold or greater changes in resting/proliferating zone

\begin{tabular}{|c|c|c|}
\hline Gene Name & Gene Description & Fold Change (CNP/Control) \\
\hline Spock3 & sparc/osteonectin, cwcv and kazal-like domains proteoglycan 3 & 2.76 \\
\hline 1115 & interleukin 15 & 2.73 \\
\hline Mgst2 & microsomal glutathione S-transferase 2 & 2.60 \\
\hline Alcam & activated leukocyte cell adhesion molecule & 2.52 \\
\hline Tec & cytoplasmic tyrosine kinase, Dscr28C related (Drosophila) & 2.27 \\
\hline Aard & alanine and arginine rich domain containing protein & 2.24 \\
\hline Tnfsfl। & tumor necrosis factor (ligand) superfamily, member II & 2.18 \\
\hline Vegfc & vascular endothelial growth factor $\mathrm{C}$ & 2.18 \\
\hline Senp8 & SUMO/sentrin specific protease family member 8 & 2.09 \\
\hline Pde4b & phosphodiesterase 4B, cAMP specific & 2.02 \\
\hline Gcnt2 & glucosaminyl (N-acetyl) transferase 2, I-branching enzyme & 0.18 \\
\hline Cidea & cell death-inducing DNA fragmentation factor, alpha subunit-like & 0.24 \\
\hline Frzb & frizzled-related protein & 0.28 \\
\hline F5 & coagulation factor $\mathrm{V}$ & 0.31 \\
\hline Car8 & carbonic anhydrase 8 & 0.32 \\
\hline lbsp & integrin binding sialoprotein & 0.34 \\
\hline Lifr & leukemia inhibitory factor receptor & 0.36 \\
\hline Colloal & procollagen, type $\mathrm{X}$, alpha I & 0.37 \\
\hline Lepr & leptin receptor & 0.37 \\
\hline Ibsp & integrin binding sialoprotein & 0.38 \\
\hline Pthrl & parathyroid hormone receptor I & 0.38 \\
\hline Clcn7 & chloride channel 7 & 0.41 \\
\hline Chd7 & chromodomain helicase DNA binding protein 7 & 0.42 \\
\hline H2-DMa & histocompatibility 2 , class II, locus DMa & 0.42 \\
\hline Coll3al & procollagen, type XIII, alpha I & 0.42 \\
\hline Cntnl & contactin I & 0.43 \\
\hline Slc7a3 & solute carrier family 7, member 3 & 0.44 \\
\hline Tm7sfl & transmembrane 7 superfamily member I & 0.45 \\
\hline Iqsecl & IQ motif and Sec7 domain I & 0.45 \\
\hline Pthlh & parathyroid hormone-like peptide & 0.46 \\
\hline Pdzk3 & PDZ domain containing 2 & 0.46 \\
\hline Tmie & transmembrane inner ear & 0.47 \\
\hline Ifitm5 & interferon induced transmembrane protein 5 & 0.47 \\
\hline Socs2 & suppressor of cytokine signaling 2 & 0.47 \\
\hline Angptl2 & angiopoietin-like 2 & 0.48 \\
\hline Capn6 & calpain 6 & 0.48 \\
\hline Atplod & ATPase, Class V, type I0D & 0.48 \\
\hline Cald I & caldesmon I & 0.49 \\
\hline Phtf2 & putative homeodomain transcription factor 2 & 0.50 \\
\hline
\end{tabular}

We also performed KEGG analyses of CNP-regulated genes in the other zones. In the proliferative zone, genes involved in cytokine receptor interactions were most prominent with four genes, three of each were upregulated by CNP (Table 1). The categories of cell adhesion and focal adhesion molecules were represented by three genes each (data not shown). In contrast, no category was represented by more than two genes in the mineralized zone (data not shown).

\section{Discussion}

Gene disruption and other studies have identified the CNP pathway as one of the most important anabolic regulators of endochondral bone growth. However, the molecular and cellular mechanisms involved are not completely understood. Here we provide multiple novel insights into these mechanisms. Most importantly, we show that the p38 MAP kinase pathway is an essential mediator of CNP effects on endochondral bone growth. Second, we identify the hypertrophic zone of the growth plate as the main target of CNP signaling, likely because of the high levels of cGMP-dependent kinase I and II expression in this zone. Third, we used genome-wide microarray analyses to identify multiple target genes potentially involved in CNP effects in cartilage.

Earlier studies have demonstrated that CNP stimulates bone growth through enhanced proliferation, mineraliza- 
Table 2: Genes showing 2-fold or greater changes in mineralized zone

\begin{tabular}{|c|c|c|}
\hline Gene Name & Gene Description & Fold Change (CNP/Control) \\
\hline Ptgs2 & prostaglandin-endoperoxide synthase 2 & 2.87 \\
\hline Bcan & brevican & 2.75 \\
\hline Gabrb3 & $\begin{array}{l}\text { gamma-aminobutyric acid (GABA-A) receptor, } \\
\text { subunit beta } 3\end{array}$ & 2.46 \\
\hline Robo4 & roundabout homolog 4 (Drosophila) & 2.31 \\
\hline $\mathrm{Cd} 38$ & CD38 antigen & 2.23 \\
\hline Lepr & leptin receptor & 2.22 \\
\hline $\mathrm{Cd} 24 \mathrm{a}$ & CD24a antigen & 2.15 \\
\hline Tgfbi & transforming growth factor, beta induced & 2.14 \\
\hline Tmem56 & transmembrane protein 56 & 2.12 \\
\hline Gsg2 & germ cell-specific gene 2 & 2.11 \\
\hline Dspg3 & dermatan sulphate proteoglycan 3 & 2.11 \\
\hline Siat4c & $\begin{array}{l}\text { sialyltransferase } 4 C \text { (beta-galactoside alpha-2,3- } \\
\text { sialytransferase) }\end{array}$ & 2.04 \\
\hline Hbb-y & hemoglobin $\mathrm{Y}$, beta-like embryonic chain & 0.21 \\
\hline Zbtb8 & zinc finger and BTB domain containing 8 & 0.24 \\
\hline Chicl & cysteine-rich hydrophobic domain I & 0.27 \\
\hline Mia & EGL nine homolog 2 (C. elegans) & 0.28 \\
\hline Nox4 & NADPH oxidase 4 & 0.29 \\
\hline Fgd6 & FYVE, RhoGEF and PH domain containing 6 & 0.32 \\
\hline Ddc & dopa decarboxylase & 0.34 \\
\hline Crxosl & Crx opposite strand transcript I & 0.37 \\
\hline Hapln I & cartilage link protein I & 0.37 \\
\hline Col27al & procollagen, type XXVII, alpha I & 0.38 \\
\hline Fgd5 & FYVE, RhoGEF and PH domain containing 5 & 0.38 \\
\hline Msi2h & Musashi homolog 2 (Drosophila) & 0.39 \\
\hline RgsII & regulator of G-protein signaling II & 0.42 \\
\hline Mrpl35 & mitochondrial ribosomal protein $\mathrm{L} 35$ & 0.43 \\
\hline Wwp2 & $\begin{array}{l}\text { WW domain containing E3 ubiquitin protein } \\
\text { ligase } 2\end{array}$ & 0.44 \\
\hline Glt25d2 & glycosyltransferase 25 domain containing 2 & 0.44 \\
\hline Zcchc5 & zinc finger, $\mathrm{CCHC}$ domain containing 5 & 0.45 \\
\hline Stno & strawberry notch homolog (Drosophila) & 0.46 \\
\hline Ppplr3c & $\begin{array}{l}\text { protein phosphatase I, regulatory (inhibitor) } \\
\text { subunit } 3 C\end{array}$ & 0.46 \\
\hline Col9a3 & procollagen, type IX, alpha 3 & 0.47 \\
\hline lgf2 & insulin-like growth factor 2 & 0.47 \\
\hline Edil3 & EGF-like repeats and discordin I-like domains 3 & 0.48 \\
\hline Ttll3 & tubulin tyrosine ligase-like family, member 3 & 0.48 \\
\hline $\mathrm{A} 2 \mathrm{~m}$ & alpha-2-macroglobulin & 0.49 \\
\hline Ctfl & cardiotrophin I & 0.49 \\
\hline Xist & inactive $X$ specific transcripts & 0.49 \\
\hline Zfp458 & zinc finger protein 458 & 0.50 \\
\hline
\end{tabular}

tion and extracellular matrix synthesis $[10,12,13]$. Our data suggest that effects of CNP on longitudinal bone growth are largely due to the expansion of the hypertrophic zone, in agreement with earlier studies [23]. This could be due, in principle, to a number of effects, such as increased rate of generation of hypertrophic chondrocytes, increased size of individual hypertrophic chondrocytes, and delayed replacement of hypertrophic cartilage by bone. It should be noted that these possibilities are not exclusive, and several or all of them can contribute to the observed effects of CNP. Multiple observations support the notion that delayed removal of hypertrophic chondrocytes is one of the mechanisms involved in CNP-induced bone growth. First, terminal hypertrophic chondrocytes at the metaphysis reach a larger size, suggesting that a delay in chondrocyte replacement by bone tissue allows for a longer period of cellular growth. Furthermore, while CNP increases the size of the entire tibia significantly, this increase is not matched by a proportional increase in the area of the mineralized region. This observation suggests that CNP delays remodeling of the metaphysis and the replacement of cartilage by bone. Finally, our microarray 
Table 3: Genes showing 2-fold or greater changes in hypertrophic zone

\begin{tabular}{|c|c|c|}
\hline Gene Name & Gene Description & Fold Change (CNP/Control) \\
\hline Cxcll4 & chemokine (C-X-C motif) ligand I4 & 7.15 \\
\hline Ptgs2 & prostaglandin-endoperoxide synthase 2 & 6.77 \\
\hline Grem I & cysteine knot superfamily I, BMP antagonist I & 6.47 \\
\hline $\mathrm{Fbxo32}$ & F-box only protein 32 & 5.87 \\
\hline Glipr I & GLI pathogenesis-related I (glioma) & 5.22 \\
\hline Gdf5 & growth differentiation factor 5 & 4.93 \\
\hline Nox4 & NADPH oxidase 4 & 3.78 \\
\hline Ebi2 & Epstein-Barr virus induced gene 2 & 3.78 \\
\hline Evil & ecotropic viral integration site I & 3.50 \\
\hline Prnd & prion protein dublet & 3.43 \\
\hline Acdc & adipocyte complement related protein & 3.42 \\
\hline Nes & nestin & 3.33 \\
\hline Tnnt3 & troponin T3, skeletal, fast & 3.29 \\
\hline Nox4 & NADPH oxidase 4 & 3.27 \\
\hline Rbpl & retinol binding protein I, cellular & 3.19 \\
\hline Histlh2bc & histone $\mathrm{I}, \mathrm{H} 2 \mathrm{bp}$ & 3.16 \\
\hline Inhbb & inhibin beta-B & 3.12 \\
\hline Sox 17 & SRY-box containing gene 17 & 3.10 \\
\hline Rnfl 25 & ring finger protein 125 & 3.08 \\
\hline Fabp4 & fatty acid binding protein 4 , adipocyte & 3.07 \\
\hline $\mathrm{Clql3}$ & Clq-like 3 & 3.03 \\
\hline Rbpms & RNA binding protein gene with multiple splicing & 3.02 \\
\hline Nrarp & Notch-regulated ankyrin repeat protein & 3.02 \\
\hline Mmrn2 & multimerin 2 & 3.00 \\
\hline Cldn5 & claudin 5 & 3.00 \\
\hline Cd44 & CD44 antigen & 2.99 \\
\hline $\mathrm{K} \operatorname{lh} 14$ & kelch-like 4 (Drosophila) & 2.98 \\
\hline Pscd4 & $\begin{array}{l}\text { pleckstrin homology, Sec7 and coiled/coil } \\
\text { domains } 4\end{array}$ & 2.90 \\
\hline Ptprc & protein tyrosine phosphatase, receptor type, C & 2.86 \\
\hline Rasgrpl & RAS guanyl releasing protein I & 2.85 \\
\hline Ptger2 & prostaglandin E receptor 2 (subtype EP2) & 2.84 \\
\hline Ctla2b & trophoblast specific protein beta & 2.84 \\
\hline Copg2as2 & $\begin{array}{l}\text { coatomer protein complex, subunit gamma } 2 \text {, } \\
\text { antisense } 2\end{array}$ & 2.82 \\
\hline lan I & immune associated nucleotide I & 2.82 \\
\hline Pmaipl & $\begin{array}{l}\text { phorbol-12-myristate-13-acetate-induced } \\
\text { protein I }\end{array}$ & 2.77 \\
\hline Gpihbpl & GPI-anchored HDL-binding protein I & 2.73 \\
\hline Cdh5 & cadherin 5 & 2.69 \\
\hline Niban & niban protein & 2.67 \\
\hline Ptpn3 & $\begin{array}{l}\text { protein tyrosine phosphatase, non-receptor } \\
\text { type } 3\end{array}$ & 2.67 \\
\hline Slc26a7 & solute carrier family 26, member 7 & 2.67 \\
\hline Tm6sfl & transmembrane 6 superfamily member I & 2.65 \\
\hline Pkp2 & plakophilin 2 & 2.65 \\
\hline Bcl2ala & $\begin{array}{l}\text { B-cell leukemia/lymphoma } 2 \text { related protein } \\
\text { Ala }\end{array}$ & 2.63 \\
\hline Prss8 & protease, serine, 8 (prostasin) & 2.61 \\
\hline Fads3 & fatty acid desaturase 3 & 2.60 \\
\hline Runxl & runt related transcription factor I & 2.56 \\
\hline Abcc 9 & $\begin{array}{l}\text { ATP-binding cassette, sub-family C (CFTR/ } \\
\text { MRP), member } 9\end{array}$ & 2.56 \\
\hline $\mathrm{Nr} 2 \mathrm{fl}$ & nuclear receptor subfamily 2 , group $F$, member & 2.55 \\
\hline Hbb-y & hemoglobin $\mathrm{Y}$, beta-like embryonic chain & 2.52 \\
\hline Akrlb8 & aldo-keto reductase family I, member B8 & 2.51 \\
\hline Siat8f & $\begin{array}{l}\text { sialyltransferase } 8 \text { (alpha-2, 8-sialyltransferase) } \\
\text { F }\end{array}$ & 2.51 \\
\hline Sfpil & SFFV proviral integration I & 2.51 \\
\hline
\end{tabular}


Table 3: Genes showing 2-fold or greater changes in hypertrophic zone (Continued)

\begin{tabular}{|c|c|c|}
\hline Zbtb33 & zinc finger and BTB domain containing 33 & 2.49 \\
\hline Gdpd I & $\begin{array}{l}\text { glycerophosphodiester phosphodiesterase } \\
\text { domain containing I }\end{array}$ & 2.46 \\
\hline Clecsf6 & C-type lectin, superfamily member 6 & 2.46 \\
\hline Pstpip I & $\begin{array}{l}\text { proline-serine-threonine phosphatase- } \\
\text { interacting protein I }\end{array}$ & 2.45 \\
\hline Esam I & endothelial cell-specific adhesion molecule & 2.44 \\
\hline CdhI3 & cadherin 13 & 2.43 \\
\hline Hist $2 \mathrm{~h} 3 \mathrm{c} 2$ & histone 2, $\mathrm{H} 2 \mathrm{aal}$ & 2.43 \\
\hline Sfrp2 & secreted frizzled-related sequence protein 2 & 2.40 \\
\hline Cables I & $\mathrm{Cdk5}$ and $\mathrm{Abl}$ enzyme substrate I & 2.39 \\
\hline Ednrb & endothelin receptor type B & 2.39 \\
\hline Eltd l & $\begin{array}{l}\text { EGF, latrophilin seven transmembrane domain } \\
\text { containing I }\end{array}$ & 2.38 \\
\hline Calcrl & calcitonin receptor-like & 2.38 \\
\hline Ctla2b & trophoblast specific protein beta & 2.38 \\
\hline lan I & immune associated nucleotide I & 2.36 \\
\hline Sox 18 & SRY-box containing gene 18 & 2.36 \\
\hline Plcel & phospholipase C, epsilon I & 2.33 \\
\hline III3ral & interleukin 13 receptor, alpha I & 2.33 \\
\hline $\mathrm{Cd} 38$ & CD38 antigen & 2.32 \\
\hline Ncf4 & neutrophil cytosolic factor 4 & 2.30 \\
\hline Rgs4 & regulator of G-protein signaling 4 & 2.30 \\
\hline Ptpn8 & $\begin{array}{l}\text { protein tyrosine phosphatase, non-receptor } \\
\text { type } 8\end{array}$ & 2.29 \\
\hline Inhba & inhibin beta- $A$ & 2.29 \\
\hline Alcam & activated leukocyte cell adhesion molecule & 2.27 \\
\hline Piral & paired-lg-like receptor $\mathrm{Al}$ & 2.27 \\
\hline Cav2 & caveolin 2 & 2.27 \\
\hline Cxcr4 & chemokine (C-X-C motif) receptor 4 & 2.26 \\
\hline Sh3bp5 & calpain 7 & 2.26 \\
\hline Mfap3l & microfibrillar-associated protein 3-like & 2.26 \\
\hline Dscrl & $\begin{array}{l}\text { Down syndrome critical region homolog I } \\
\text { (human) }\end{array}$ & 2.25 \\
\hline Mcam & melanoma cell adhesion molecule & 2.24 \\
\hline Ms4a6d & $\begin{array}{l}\text { membrane-spanning 4-domains, subfamily } A \text {, } \\
\text { member } 6 D\end{array}$ & 2.24 \\
\hline $\mathrm{Cd} 34$ & CD34 antigen & 2.24 \\
\hline Zfp42 & zinc finger protein 42 & 2.23 \\
\hline Kcne3 & $\begin{array}{l}\text { potassium voltage-gated channel, Isk-related } \\
\text { subfamily, gene } 3\end{array}$ & 2.22 \\
\hline Ivnslabp & influenza virus NSIA binding protein & 2.22 \\
\hline Cd84 & CD84 antigen & 2.22 \\
\hline $\mathrm{Kdr}$ & kinase insert domain protein receptor & 2.21 \\
\hline $\mathrm{Clca} 5$ & chloride channel calcium activated 5 & 2.20 \\
\hline $\operatorname{ltga} 9$ & integrin alpha 9 & 2.19 \\
\hline Prkch & protein kinase $C$, eta & 2.19 \\
\hline TexI5 & testis expressed gene 15 & 2.18 \\
\hline Plac8 & placenta-specific 8 & 2.17 \\
\hline Ebf3 & early B-cell factor 3 & 2.16 \\
\hline Lcp2 & lymphocyte cytosolic protein 2 & 2.16 \\
\hline Mcoln3 & mucolipin 3 & 2.15 \\
\hline Sh3glbl & SH3-domain GRB2-like BI (endophilin) & 2.15 \\
\hline Ugtla2 & $\begin{array}{l}\text { UDP glycosyltransferase I family, polypeptide } \\
\text { A6 }\end{array}$ & 2.15 \\
\hline Egfl7 & EGF-like domain 7 & 2.15 \\
\hline Icam2 & intercellular adhesion molecule 2 & 2.15 \\
\hline Sixl & $\begin{array}{l}\text { sine oculis-related homeobox I homolog } \\
\text { (Drosophila) }\end{array}$ & 2.14 \\
\hline Chst7 & $\begin{array}{l}\text { carbohydrate }(\mathrm{N} \text {-acetylglucosamino) } \\
\text { sulfotransferase } 7\end{array}$ & 2.13 \\
\hline Evi2a & ecotropic viral integration site $2 \mathrm{a}$ & 2.12 \\
\hline Myctl & myc target I & 2.12 \\
\hline Pde4b & phosphodiesterase 4B, cAMP specific & 2.12 \\
\hline
\end{tabular}


Table 3: Genes showing 2-fold or greater changes in hypertrophic zone (Continued)

\begin{tabular}{|c|c|c|}
\hline Adamts I & $\begin{array}{l}\text { a disintegrin-like \& metalloprotease with } \\
\text { thrombospondin type I }\end{array}$ & 2.10 \\
\hline Snx 10 & sorting nexin 10 & 2.10 \\
\hline Rac2 & RAS-related C 3 botulinum substrate 2 & 2.09 \\
\hline Siat8d & $\begin{array}{l}\text { sialyltransferase } 8 \text { (alpha-2, 8-sialyltransferase) } \\
\text { D }\end{array}$ & 2.08 \\
\hline Dsg2 & desmoglein 2 & 2.07 \\
\hline FIIr & FII receptor & 2.06 \\
\hline Lrrc33 & leucine rich repeat containing 33 & 2.06 \\
\hline $\operatorname{lan} 9$ & $\begin{array}{l}\text { Similar to hypothetical protein (LOC243374), } \\
\text { mRNA }\end{array}$ & 2.06 \\
\hline Slc30al & $\begin{array}{l}\text { solute carrier family } 30 \text { (zinc transporter), } \\
\text { member I }\end{array}$ & 2.05 \\
\hline Kcnj8 & $\begin{array}{l}\text { potassium inwardly-rectifying channel, } \\
\text { subfamily J, member } 8\end{array}$ & 2.05 \\
\hline Cotll & coactosin-like I (Dictyostelium) & 2.04 \\
\hline Ptx3 & pentaxin related gene & 2.04 \\
\hline Ctla2b & trophoblast specific protein beta & 2.03 \\
\hline Sipa l & signal-induced proliferation associated gene I & 2.03 \\
\hline Rgs5 & regulator of G-protein signaling 5 & 2.03 \\
\hline Itgax & integrin alpha $X$ & 2.01 \\
\hline Car2 & carbonic anhydrase 2 & 2.01 \\
\hline Serpind I & $\begin{array}{l}\text { serine (or cysteine) proteinase inhibitor, clade } \\
\text { D, member I }\end{array}$ & 2.01 \\
\hline Cadps2 & $\begin{array}{l}\text { Ca2+-dependent activator protein for } \\
\text { secretion } 2\end{array}$ & 2.00 \\
\hline$|l| r \mid 2$ & interleukin I receptor-like 2 & 2.00 \\
\hline Lemd I & LEM domain containing I & 0.06 \\
\hline Gzme & granzyme E & 0.14 \\
\hline Plekha7 & $\begin{array}{l}\text { pleckstrin homology domain containing, family } \\
\text { A member } 7\end{array}$ & 0.14 \\
\hline Chad & chondroadherin & 0.15 \\
\hline $\mathrm{Cd} 28$ & CD28 antigen & 0.17 \\
\hline Sep-04 & septin 4 & 0.19 \\
\hline Pltp & phospholipid transfer protein & 0.19 \\
\hline 1115 & interleukin 15 & 0.20 \\
\hline Ttll3 & tubulin tyrosine ligase-like family, member 3 & 0.20 \\
\hline Syt8 & synaptotagmin 8 & 0.20 \\
\hline Gpr9l & G protein-coupled receptor 91 & 0.23 \\
\hline Sep-04 & septin 4 & 0.24 \\
\hline $\mathrm{Cd} 28$ & CD28 antigen & 0.24 \\
\hline Efempl & $\begin{array}{l}\text { epidermal growth factor-containing fibulin-like } \\
\text { ECM protein I }\end{array}$ & 0.25 \\
\hline Tnfsfl I & $\begin{array}{l}\text { tumor necrosis factor (ligand) superfamily, } \\
\text { member II }\end{array}$ & 0.27 \\
\hline TIr I & toll-like receptor I & 0.28 \\
\hline Trim2 & tripartite motif protein 2 & 0.28 \\
\hline Vnnl & vanin I & 0.28 \\
\hline Tnni2 & troponin I, skeletal, fast 2 & 0.29 \\
\hline Enpp6 & $\begin{array}{l}\text { ectonucleotide pyrophosphatase/ } \\
\text { phosphodiesterase } 6\end{array}$ & 0.30 \\
\hline Fxyd2 & $\begin{array}{l}\text { FXYD domain-containing ion transport } \\
\text { regulator } 2\end{array}$ & 0.30 \\
\hline Rtn2 & reticulon 2 (Z-band associated protein) & 0.31 \\
\hline lqgap2 & IQ motif containing GTPase activating protein 2 & 0.31 \\
\hline Capn6 & calpain 6 & 0.32 \\
\hline Rab27a & RAB27A, member RAS oncogene family & 0.32 \\
\hline Aicda & activation-induced cytidine deaminase & 0.33 \\
\hline F5 & coagulation factor $V$ & 0.33 \\
\hline Hs6st2 & heparan sulfate 6 -O-sulfotransferase 2 & 0.33 \\
\hline Cklfsf8 & chemokine-like factor super family 8 & 0.33 \\
\hline Nrk & Nik related kinase & 0.33 \\
\hline
\end{tabular}


Table 3: Genes showing 2-fold or greater changes in hypertrophic zone (Continued)

\begin{tabular}{|c|c|c|}
\hline Gprasp2 & $\begin{array}{l}\text { G protein-coupled receptor associated sorting } \\
\text { protein } 2\end{array}$ & 0.33 \\
\hline Car8 & carbonic anhydrase 8 & 0.34 \\
\hline Prom I & prominin I & 0.34 \\
\hline Mgst2 & microsomal glutathione S-transferase 2 & 0.34 \\
\hline Pltp & phospholipid transfer protein & 0.35 \\
\hline Stc2 & stanniocalcin 2 & 0.35 \\
\hline Lipg & lipase, endothelial & 0.35 \\
\hline $1117 d$ & interleukin I7D & 0.36 \\
\hline Serpinb6b & $\begin{array}{l}\text { serine (or cysteine) proteinase inhibitor, clade } \\
\mathrm{B}, \text { member } 6 \mathrm{~b}\end{array}$ & 0.36 \\
\hline Matn3 & matrilin 3 & 0.37 \\
\hline Slclal & solute carrier family I, member I & 0.37 \\
\hline Art3 & ADP-ribosyltransferase 3 & 0.37 \\
\hline$C_{p}$ & ceruloplasmin & 0.37 \\
\hline Abi3bp & $\begin{array}{l}\mathrm{ABI} \text { gene family, member } 3 \text { (NESH) binding } \\
\text { protein }\end{array}$ & 0.37 \\
\hline Matn I & matrilin I, cartilage matrix protein I & 0.38 \\
\hline $\mathrm{A} 2 \mathrm{~m}$ & alpha-2-macroglobulin & 0.38 \\
\hline Uspll & ubiquitin specific protease II & 0.38 \\
\hline Col9a2 & procollagen, type IX, alpha 2 & 0.39 \\
\hline Pik3rl & $\begin{array}{l}\text { phosphatidylinositol 3-kinase, regulatory } \\
\text { subunit, polypeptide I }\end{array}$ & 0.39 \\
\hline Rlbpl & retinaldehyde binding protein I & 0.39 \\
\hline Rnase4 & ribonuclease, RNase A family 4 & 0.39 \\
\hline Coll4al & procollagen, type XIV, alpha I & 0.40 \\
\hline Slcl9a3 & $\begin{array}{l}\text { solute carrier family } 19 \text { (sodium/hydrogen } \\
\text { exchanger), member } 3\end{array}$ & 0.40 \\
\hline Nfkbiz & $\begin{array}{l}\text { NFK light polypeptide gene enhancer in B-cells } \\
\text { inhibitor, zeta }\end{array}$ & 0.40 \\
\hline Slco2bl & $\begin{array}{l}\text { solute carrier organic anion transporter family, } \\
\text { member } 2 \mathrm{bl}\end{array}$ & 0.41 \\
\hline Fxyd6 & $\begin{array}{l}\text { FXYD domain-containing ion transport } \\
\text { regulator } 6\end{array}$ & 0.41 \\
\hline Egr3 & early growth response 3 & 0.41 \\
\hline Usp53 & ubiquitin specific peptidase 53 & 0.41 \\
\hline Serpinil & $\begin{array}{l}\text { serine (or cysteine) proteinase inhibitor, clade } \\
\text { I, member I }\end{array}$ & 0.41 \\
\hline Pitpncl & $\begin{array}{l}\text { phosphatidylinositol transfer protein, } \\
\text { cytoplasmic I }\end{array}$ & 0.42 \\
\hline Anxa8 & annexin $A 8$ & 0.42 \\
\hline $1117 \mathrm{~b}$ & interleukin I7B & 0.43 \\
\hline GprI26 & G protein-coupled receptor 126 & 0.43 \\
\hline Pankl & pantothenate kinase I & 0.43 \\
\hline Dock9 & dedicator of cytokinesis 9 & 0.43 \\
\hline Sfmbt2 & Scm-like with four mbt domains 2 & 0.43 \\
\hline Enpp2 & $\begin{array}{l}\text { ectonucleotide pyrophosphatase/ } \\
\text { phosphodiesterase } 2\end{array}$ & 0.44 \\
\hline Kctd4 & $\begin{array}{l}\text { potassium channel tetramerisation domain } \\
\text { containing } 4\end{array}$ & 0.44 \\
\hline Coblll & Cobl-like I & 0.44 \\
\hline Scrgl & scrapie responsive gene I & 0.45 \\
\hline Matn3 & matrilin 3 & 0.45 \\
\hline Zfpm2 & zinc finger protein, multitype 2 & 0.45 \\
\hline Lims2 & LIM and senescent cell antigen like domains 2 & 0.45 \\
\hline Gpr64 & G protein-coupled receptor 64 & 0.45 \\
\hline Ptprzl & $\begin{array}{l}\text { protein tyrosine phosphatase, receptor type Z, } \\
\text { polypeptide I }\end{array}$ & 0.46 \\
\hline Hhip & Hedgehog-interacting protein & 0.46 \\
\hline Eps8 & $\begin{array}{l}\text { epidermal growth factor receptor pathway } \\
\text { substrate } 8\end{array}$ & 0.46 \\
\hline Heph & hephaestin & 0.47 \\
\hline Sesn I & sestrin I & 0.47 \\
\hline Ctfl & cardiotrophin I & 0.47 \\
\hline
\end{tabular}


Table 3: Genes showing 2-fold or greater changes in hypertrophic zone (Continued)

\begin{tabular}{lll}
\hline Zfp6I2 & Zinc finger protein 6I2 & 0.48 \\
Wdr40b & WD repeat domain 40B & 0.48 \\
DkkI & dickopf homolog I (Xenopus laevis) & 0.48 \\
Ogt & O-linked N-acetylglucosamine (GlcNAc) & 0.48 \\
& transferase & 0.48 \\
Ddc & dopa decarboxylase & 0.48 \\
Adaml7 & a disintegrin and metallopeptidase domain I7 & 0.48 \\
Rdhe2 & short chain dehydrogenase reductase 9 & 0.48 \\
Vav3 & vav 3 oncogene & 0.48 \\
Tmem56 & transmembrane protein 56 & 0.48 \\
Aldhla3 & aldehyde dehydrogenase family I, subfamily A3 \\
Zfp52I & ecotropic viral integration site 3 & 0.48 \\
Fbxo25 & F-box only protein 25 & 0.49 \\
Kitl & kit ligand & 0.49 \\
PlaglI & pleiomorphic adenoma gene-like I \\
Hectd2 & HECT domain containing 2 & 0.49 \\
Bmper & BMP-binding endothelial regulator & 0.49 \\
Gpraspl & G protein-coupled receptor associated sorting \\
Gdfl0 & protein I & 0.49 \\
Sox5 & growth differentiation factor 10 & 0.50 \\
\end{tabular}

data show that expression of RANKL, a potent activator of osteoclastic bone resorption, in the hypertrophic zone is down-regulated by CNP. RANKL is expressed in hypertrophic cartilage [35-37], where it likely stimulates the removal of hypertrophic cartilage by osteoclasts and facilitates vascular invasion and ossification. Repression of RANKL expression by CNP could thus delay these remodeling events. Experiments are under way in our laboratory to examine whether osteoclast activity is indeed reduced in CNP-treated organ cultures.

We and others have shown important roles of p38 in hypertrophic chondrocyte differentiation in vitro and in vivo $[3,27,38-41]$. Thus, it is not surprising that p38 inhibition reverses CNP effects on longitudinal growth and the expansion of the hypertrophic zone. Moreover, our data show that p38 activity is required for the repression of mineralization by CNP. These data are in agreement with a recent study showing delayed primary and secondary ossification in transgenic mice overexpressing an activated form of MKK6, an upstream activator of p38, in cartilage [27]. It should be noted, however, that other phenotypes of these mice (such as reduced proliferation and delayed hypertrophy) are not recapitulated in our studies, potentially due to altered patterns and/or levels of p38 activation in the two studies (e.g. transgenic expression of activated MKK6 under the collagen II promoter versus activation of p38 through the endogenous NPR2/cGMP signaling cascade) or because CNP acts through additional pathways besides p38. Independent of these complications, our studies provide strong evidence for a novel function of p38 signaling in maintaining hypertrophic cartilage and delaying the replacement of cartilage by bone.
However, our data also show that p38 signaling is not required for all effects of $\mathrm{CNP}$ on hypertrophic cartilage. While p38 inhibition results in lower basal levels of Cox2 mRNA in chondrocytes, in agreement with observations by other studies [42-44], CNP still causes a strong increase in Cox2 expression in the presence of SB202190. Similarly, Npr3 induction by CNP is independent of p38 activity. Therefore, it appears likely that p38 signaling is required to achieve and/or maintain the expanded hypertrophic zone in CNP-treated bones, but not for induction of some target genes. Studies to identify additional signaling pathways connecting CNP to Cox2 gene expression are underway in our laboratory.

Our studies also demonstrate antagonistic roles of p38 and another MAP kinase pathway, the MEK1/2-ERK1/2 pathway. Inhibition of MEK $1 / 2$ activity results in enhanced growth of endochondral bones, with no additive or synergistic effect with CNP. While our studies were in progress, other groups showed that the MEK1/2-ERK1/ 2 indeed reduces endochondral bone growth in vivo [26] and that CNP inhibits ERK1/2 activity [21], in agreement with our studies. Additional studies confirmed the close and reciprocal interactions between CNP-cGMP and FGFMEK1/2-ERK signaling [22,23]. For example, CNP was shown to repress FGF-induced growth arrest and extracellular matrix degradation by counteracting MEK1/2 activation, while FGFs 2 and 18 suppress CNP-stimulated cGMP production $[22,23]$. However, none of these studies evaluated a potential role of p38 signaling in this context. Since p38 has also been implicated in FGF signal transduction in chondrocytes $[45,46]$, it will be interesting to investigate whether this MAP kinase is involved in the antagonistic effects of CNP and FGF in endochondral 

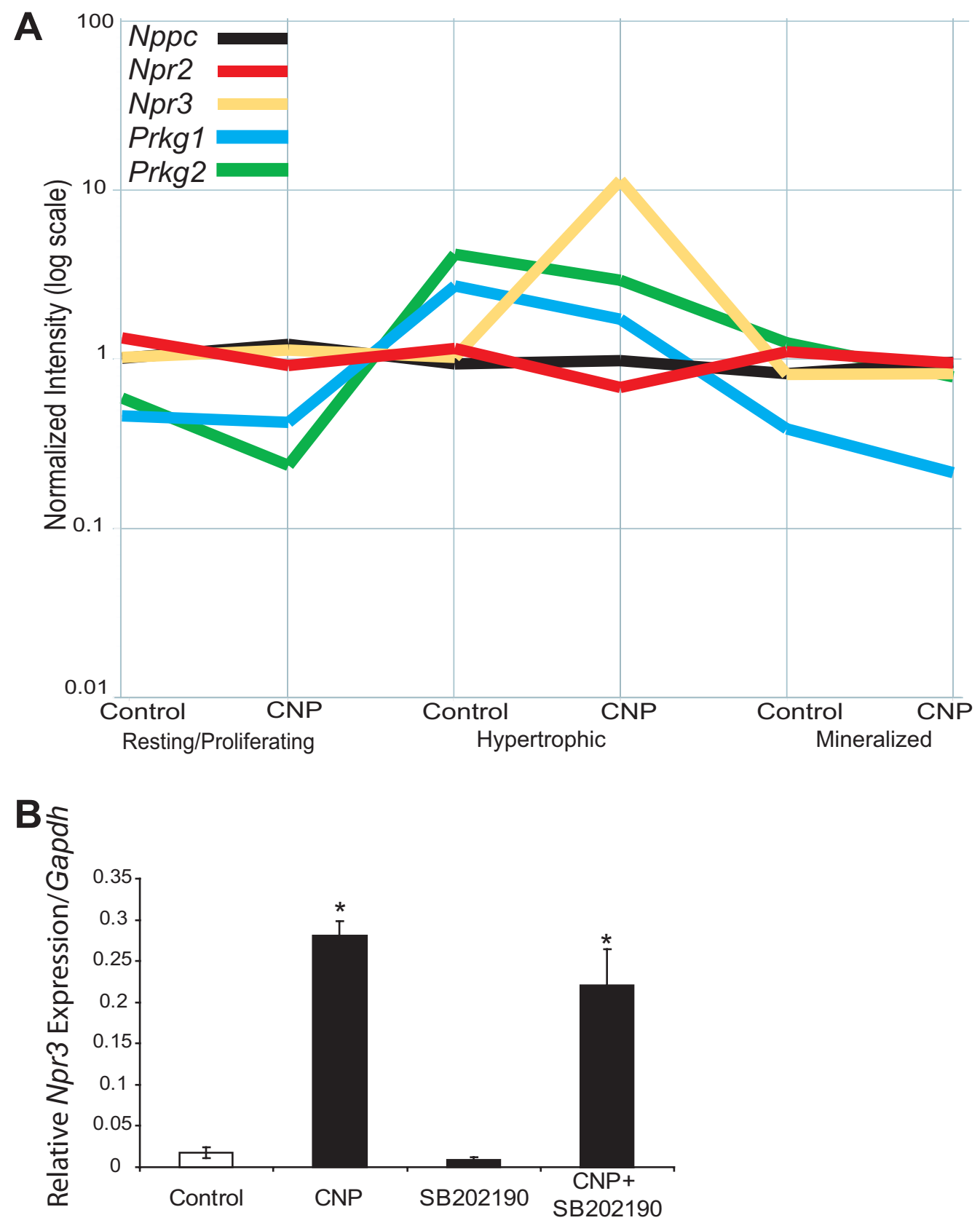

\section{Figure 7}

Expression patterns from microarray analyses demonstrate up-regulation of cGMP-dependent kinase genes in the hypertrophic zone. Microarray analyses of the principal players in the CNP pathway in micro-dissected tibiae cultured with and without CNP $(I \mu \mathrm{M})$ are shown (A). PrkgI and Prgk2, encoding cGMP-dependent kinases I and II, were strongly upregulated in the hypertrophic zone, irrespectively of exogenous CNP. In addition, CNP strongly stimulated expression of Npr3, the natriuretic peptide clearance receptor, in the hypertrophic zone. Real-time analysis confirmed induction of Npr3 by CNP, which primarily occurs through a $\mathrm{p} 38$-independent manner. Data represent means \pm SD of three independent trials $(p<0.05)$. 
A

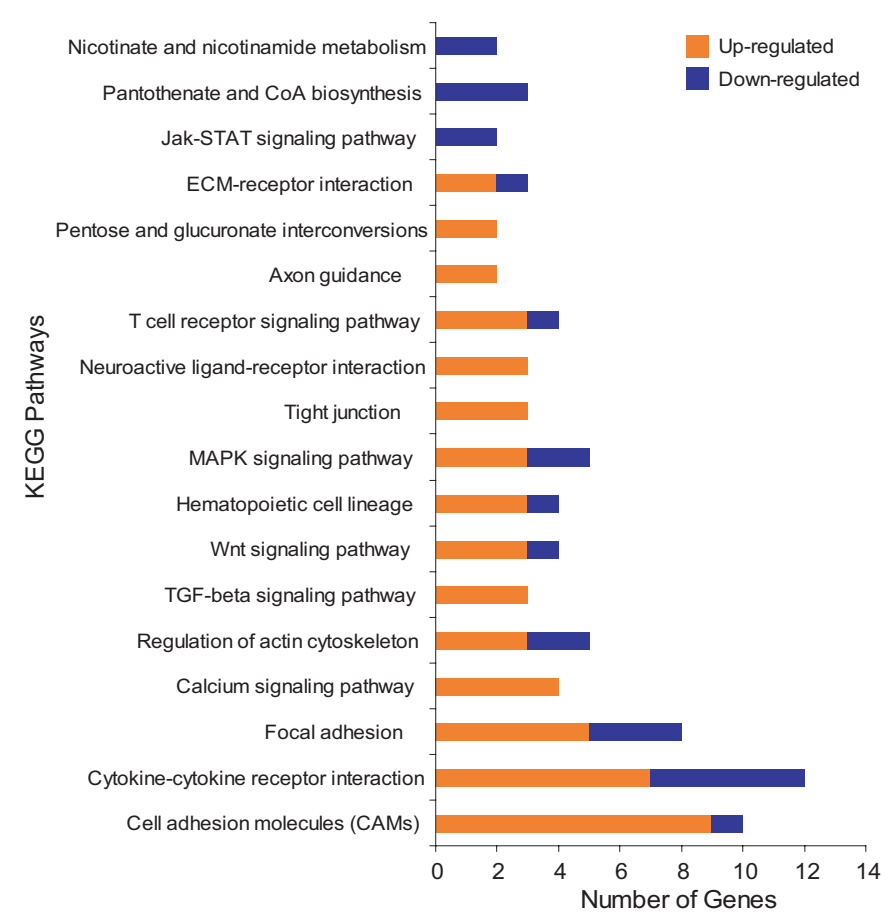

B

\begin{tabular}{llr} 
Gene & Gene Name & Fold Change \\
\hline Hedgehog & & \\
\hline Hhip & hedgehog-interacting protein & 0.46 \\
Wnt & & \\
\hline Dkk1 & Dickkopf homolog 1 (Wnt antagonist) & 0.48 \\
Srfp2 & secreted frizzled-related sequence protein 2 & 2.39 \\
& & \\
TGFß/BMP & & 0.49 \\
\hline Bmper & BMP-binding endothelial regulator & 0.5 \\
Gdf10 & Growth differentiation factor 10 & 2.28 \\
Inhba & Inhibin beta-A & 3.12 \\
Inhbb & Inhibin beta-B & 4.93 \\
Gdf5 & Growth differentiation factor 5 & 6.45 \\
Grem1 & cysteine knot superfamily 1, BMP antagonist 1 & \\
Transcription Factors & & \\
\hline Egr3 & early growth response 3 & 0.41 \\
Zfpm2 & zinc finger protein, multitype 2 (FOG2) & 0.45 \\
Sox5 & SRY-box containing gene 5 & 0.5 \\
Six1 & sine oculis-related homeobox 1 homolog & 2.15 \\
3110018A08Rik & Eb3, early B-cell factor 3 & 2.16 \\
Zfp42 & zinc finger protein 42 & 2.23 \\
Sox18 & SRY-box containing gene 18 & 2.36 \\
Nr2f1 & nuclear receptor subfamily 2, group F, member & 2.55 \\
Runx1 & runt related transcription factor 1 & 2.56 \\
Sox17 & SRY-box containing gene 17 & 3.11
\end{tabular}

\section{Figure 8}

Detailed analyses of microarray data identify CNP-regulated pathways. Microarray data sets from hypertrophic areas of micro-dissected tibiae cultured with and without CNP $(I \mu M)$ were analyzed using KEGG annotations (A). Genes upand down-regulated by CNP contributed approximately proportionally to many pathways. However, up-regulated genes dominated the cell adhesion molecules, TGFbeta and calcium signaling and tight junction categories (among others). Fold change of selected genes in the BMP/GDF, Wnt and hedgehog pathways in response to CNP is shown (as ratio of CNP to control; B). A list of transcription factor genes regulated by CNP is also shown. 
bone growth. However, both CNP and FGFs activate p38 in chondrocytes, but they have opposing effects on the growth of endochondral bones. The role of p38 in FGF effects on chondrocytes has, to our knowledge, only been studied in cell culture, not in a three-dimensional model that allows direct assessment of bone growth. Based on our data, we don't expect that p38 activation contributes to the growth-repressing activities of FGF, but this prediction needs to be experimentally verified. Nevertheless, the fact that both FGFs and CNP activate p38 despite their opposing effects on bone growth makes it unlikely that p38 contributes to crosstalk between the two signaling systems, in contrast to ERK1/2.

Similarly, it will be important to examine whether regulation of the different MAP kinases by CNP occurs through independent, parallel pathways, or whether they regulate each other. In addition, the pathways connecting CNP to the MAP kinase modules have not been completely resolved. For example, while it has been shown that repression of ERK activity by CNP occurs at the level of the upstream kinase Raf1 and requires cGMP-dependent kinase activity [22], the exact molecular mechanism involved has not been described.

This is, to our knowledge, one of the first studies to use micro-dissection of mammalian endochondral bones for genome-wide expression analyses by microarrays. We chose to perform these studies after 6 days of CNP stimulation, as opposed to a short term treatment. While this approach does not allow us to distinguish direct and indirect target genes of $\mathrm{CNP}$, it mimics the in vivo situation where cells are exposed to auto-/paracrine CNP signaling for extended periods. Our study should therefore identify genes that are regulated by long term exposure to CNP and are thus likely to be involved in the physiological activities of CNP in the growing skeleton. Our microarray data were confirmed by real-time PCR analyses for selected genes; these data and our earlier studies $[28,47,48]$ strongly suggest that the vast majority of the expression profiles detected by our microarrays correspond to the authentic gene expression patterns. Analyses of array data as well as confirmatory real-time PCRs (e.g. for type X collagen) also demonstrated that our micro-dissection protocol results in efficient separation of different zones of the cartilage and can be used for identification of novel hypertrophy-specific genes. Moreover, these data clearly show that the hypertrophic zone of the growth plate is by far the most responsive to CNP. This responsiveness does not correlate to altered levels of mRNAs for CNP itself, its signaling receptor, or the decoy receptor in control conditions. Instead, our data suggest that the expression of cGMP-dependent kinases I and II (cGKI, II) is much higher in this zone than in the other ones, providing further evidence for a crucial role of these enzymes in
CNP signal transduction. Interestingly, the expression of these two genes, as well as the Nppc and Npr2 genes, in the hypertrophic zone is not altered in response to CNP. In contrast, Npr3 expression is strongly induced by CNP in the hypertrophic zone. While this induction was not identified as significant in the microarray analyses, subsequent real-time PCR confirmed the existence of this previously unknown feedback loop that likely limits CNP effects in growing cartilage.

Our expression data suggest that both cGKI and II are involved in mediating CNP effects on cartilage development. Studies with genetically altered mice and naturally occuring rat mutants demonstrate that cGKII is the dominating protein in chondrocytes $[19,49]$; however, the cartilage phenotypes of cGKII- and CNP-deficient mice are not identical, suggesting the possibility of an additional role of cGKI in CNP signaling. Double knockout mice for both cGKI and II will be required to resolve this issue.

Thus, our data in conjunction with published studies support a model where basal CNP signaling promotes proliferation and extracellular matrix synthesis in growth plate chondrocytes. Once cells start to differentiate, they increase their expression of cGMP-dependent kinases and their responsiveness to CNP. This results in an extension of hypertrophic chondrocyte life and a delay in osteoclast and potentially vascular invasion, thus promoting maximal growth of hypertrophic chondrocytes and endochondral bone growth. At the same time, high levels of CNP signaling induce expression of $\mathrm{Npr} 3$ that ultimately limits CNP effects, allowing for expression of RANKL and for remodeling of the metaphysis. Experiments are under way to examine whether this model accurately describes cellular mechanisms of CNP signaling in endochondral ossification and to identify the molecular mechanisms involved.

Detailed analyses of our microarray data provided novel insights into biological processes regulated by CNP. CNP treatment induced the expression of several genes for cellcell interactions in the hypertrophic area (as well as the resting/proliferating zone), while at the same time repressing genes for ECM proteins. Another process regulated by CNP is signaling by TGF $\beta$ family members. Most interestingly, CNP induces expression of Gdf5 and Grem1, both of which have been implicated in skeletal development. Loss-of-function mutations of Gdf5 have been identified as cause of reduced skeletal growth in human chondrodysplasias and brachypodism mice [50]. Interestingly, GDF5 has been shown to stimulate cell adhesion in chondrocytes [51], in agreement with our data showing increased expression of both Gdf5 and cell adhesion molecules in response to CNP. Therefore, GDF5 is an excellent candidate for mediating the anabolic effects of CNP. In 
contrast, Grem1 encodes a BMP antagonist that is required for limb development and controls chondrogenesis [5256]. Moreover, Grem 1 expression is induced by BMP/GDF signaling [57-59], suggesting that its stimulation could be secondary to increased expression of Gdf5 and/or related factors (e.g. Inhbb and Inhba) in response to CNP.

In summary, our results identify several novel components and characteristics of CNP signaling during endochondral bone growth. Collectively, these studies lead to the novel concept that CNP acts, at least in part, by delaying the terminal steps of endochondral ossification, i.e. the replacement of hypertrophic cartilage by bone. Further tests of this model in vivo and elucidation of the mechanisms involved will not only result in improved understanding of endochondral bone development, but will also be crucial for the development of potential therapeutic applications.

\section{Methods \\ Materials}

Timed-pregnant CD1 mice were purchased from Charles River Canada. CNP, 8-(4-cpt) cGMP, and pharmacological inhibitors were obtained from Sigma and Calbiochem. Cell culture reagents were from Invitrogen and general chemicals from VWR. All real-time PCR probes and reagents were purchased from Applied Biosystems. The phospho-MKK3/6 (Cat. number 9231) and phospho-p38 (9216) antibodies were from Cell Signaling Technologies, and the $\beta$-actin antibody was from Sigma.

\section{Organ Culture}

Tibiae were isolated from embryonic day 15.5 (E15.5) embryos from CD1 timed-pregnant mice (Charles River Canada) using the Stemi DV4 Stereomicroscope (Zeiss). Dissection day was considered to be day 0 and tibiae were allowed to recover from dissection overnight in serumfree $\alpha$-MEM media containing 0.2\% Bovine Serum Albumin (BSA), $0.5 \mathrm{mM}$ L-glutamine, 40 units penicillin/mL and $40 \mu \mathrm{g}$ streptomycin/mL as described [60]. The following morning, bones in 24-well Falcon plates were measured using an eyepiece in the Stemi DV4 Stereomicroscope and treated with CNP $(0.01$ to $1 \mu \mathrm{M})$ or $\mathrm{BSA} / \mathrm{HCl}$ (1 $\mathrm{mM})$ vehicle, and DMSO or U0126, PD98059, PD169316, SB202190 or SB202474 (10 $\mu \mathrm{M}$ each). Media was changed every 48 hrs beginning on day 1 , and bones measured on days 1, 3, 6, and 8. Results are expressed as change in length relative to day 1. Experiments were repeated at least three times, with 4-6 bones per treatment for each trial.

For weight determination and Alizarin Red/Alcian Blue staining, 6 bones per treatment were weighed at day 6 of culture and then placed in 4\% Paraformaldehyde (PFA) in DEPC-treated PBS for overnight fixation. Subsequently, tibiae were placed in staining solution for 45-60 minutes (0.05\% Alizarin Red, 0.015\% Alcian Blue, 5\% acetic acid in $70 \%$ ethanol). Images of stained bones were taken using a Nikon SMZ1500 dissecting microscope with Photometric CoolSNAP colour digital camera (Nikon Canada) and PTI Image Master 5 program. Stained areas in images were measured using Openlab 4.0.4 software program.

For experiments requiring perichondrium removal, tibiae were isolated from embryonic 15.5 day embryos under three different modes: very loose dissection ensuring that perichondrium was intact, very careful dissection in which perichondrium was removed mechanically, and treatment of tibiae with dispase ( $3 \mathrm{mg} / \mathrm{mL}$ in PBS) for 3-5 minutes with concurrent mechanical removal of perichondrium $[61,62]$. Media was changed every two days beginning on day 1 and bone lengths measured on days 1 and 6, with change in length expressed relative to day 1 .

\section{Histology and Immunohistochemistry}

After experiment completion, tibiae were rinsed with PBS and fixed in 4\% PFA overnight. Bones were then stained with mercurochrome for visualization, placed in $10 \%$ formalin solution, and sent for embedding and sectioning in the Pathology lab at University of Western Ontario Hospital or the Molecular Pathology Core Facility at the Robarts Research Institute (London, Ontario, Canada). Following sectioning, bones were stained with hematoxylin and eosin using standard protocols. For immunohistochemistry, sections were incubated with primary anti-phosphop38 antibody (1:50 dilution) over night at $4{ }^{\circ} \mathrm{C}$. Bound antibody was visualized using the UltraVision LPValue detection system (Lab Vision) with AEC chromogen substrate (Lab Vision).

\section{RNA isolation from organ cultures and microarray analyses}

For experiments requiring RNA isolation from organ cultures, E15.5 tibiae were harvested and treated as described above with or without CNP and SB202190. On day 6 of treatment, tibiae were separated under a dissecting microscope into the resting/proliferative, hypertrophic, and mineralized areas. Same areas from approximately 24 bones were pooled per trial, in each of three independent trials. RNA was isolated following the RNeasy ${ }^{\circledR}$ Lipid Tissue Extraction protocol from Qiagen (Mississauga) and RNA integrity verified using the Agilent 2100 Bioanalyzer. Microarray analyses from three trials were performed at the London Regional Genomics Centre (London, Ontario, Canada) using MOE430 2.0 Affymetrix arrays consisting of 45,000 probe sets (covering the entire mouse genome). Results were analyzed using GeneSpring 7.2 software as described [28]. Microarray data were independently filtered using GeneSpring Bioscripts quality fil- 
ters for noise and one-way ANOVA testing, to eliminate genes that were not expressed or showed great variability between replicates. The remaining 5199 probes sets common to both filtering methods were used for all subsequent analyses. Lists of genes undergoing at least two-fold changes were analyzed using the Babelomics suite [63] and in particular the KEGG pathways module in the FatigoPlus tool.

\section{Real-Time PCR}

Real-Time PCR analysis was performed as described using Applied Biosystems 7900 HT Real-Time PCR System and TaqMan ${ }^{\circledast}$ Gene Expression Assays [28,40,64]. All probes (Npr3, Col2a1, Col10a1, Ptgs2, Tnfsf11 and Gapdh)were purchased from Applied Biosystems. Gene expression levels were determined using the Standard Curve quantitative method with Gapdh levels as the basis of comparison.

\section{Statistical Analyses}

All experiments were performed in at least three independent trials. Two-Way ANOVA (parametric) test with Bonferroni post-test were performed using the Graph Pad/ Prism software. One-way ANOVA with Bonferroni posttest and paired t-tests were used when appropriate.

\author{
List of abbreviations \\ $\mathrm{BMP}$ - bone morphogenetic protein \\ cGMP - cyclic guanosinemonophosphate \\ cGK - cGMP-dependent kinase \\ CNP - C-type natriuretic peptide \\ Cox2 - cyclooxygenase 2 \\ GDF - growth differentiation factor \\ ERK - extracellular signal-regulated kinase \\ MEK - MAP/ERK kinase \\ PCR - polymerase chain reaction
}

RANKL - receptor activator of nuclear factor kappa B ligand

TGF - transforming growth factor

\section{Authors' contributions}

H.A., S.K., R.G. and L-A.S. performed organ cultures and their analyses. H.A. and C.G.J. performed microarray analyses. R.S. provided consultation and training with organ cultures. F.B. conceived and designed the study and co- wrote the manuscript with H.A. All authors read and approved the final manuscript.

\section{Acknowledgements}

H.A. was supported by Ontario Graduate Studentships, S.K. and J.R.G. by graduate student awards from the Canadian Arthritis Network, and C.G.J. by Ontario Graduate Studentships in Science and Technology and a Canadian Institute for Health Research (CIHR) Doctoral Award. This work was supported by a Canada Research Chair Award and a ClHR/The Arthritis Society New Investigator Award and operating grants from the Canadian Institutes of Health Research and The Arthritis Society to F.B.

\section{References}

I. Karsenty G, Wagner EF: Reaching a genetic and molecular understanding of skeletal development. Dev Cell 2002, 2:389-406.

2. Olsen BR, Reginato AM, Wang W: Bone development. Annu Rev Cell Dev Biol 2000, 16:191-220.

3. Stanton LA, Underhill TM, Beier F: MAP kinases in chondrocyte differentiation. Dev Biol 2003, 263:165-75.

4. Ballock RT, O'Keefe RJ: Physiology and pathophysiology of the growth plate. Birth Defects Res Part C Embryo Today 2003, 69:123-43.

5. van der Eerden BCJ, Karperien M, Wit JM: Systemic and Local Regulation of the Growth Plate. Endocr Rev 2003, 24:782-80I.

6. Shum L, Coleman CM, Hatakeyama Y, Tuan RS: Morphogenesis and dysmorphogenesis of the appendicular skeleton. Birth Defects Res Part C Embryo Today 2003, 69:102-22.

7. Mundlos S, Olsen BR: Heritable diseases of the skeleton. Part II: Molecular insights into skeletal development-matrix components and their homeostasis. Faseb J 1997, I I:227-33.

8. Mundlos S, Olsen BR: Heritable diseases of the skeleton. Part I: Molecular insights into skeletal development-transcription factors and signaling pathways. Faseb J 1997, I I: I25-32.

9. Zelzer $E$, Olsen $B R$ : The genetic basis for skeletal diseases. Nature 2003, 423:343-8.

10. Chusho H, Tamura N, Ogawa Y, Yasoda A, Suda M, Miyazawa T, Nakamura K, Nakao K, Kurihara T, Komatsu Y, et al.: Dwarfism and early death in mice lacking $\mathrm{C}$-type natriuretic peptide. Proc Natl Acad Sci USA 200I, 98:401 6-402I.

II. Komatsu Y, Chusho H, Tamura N, Yasoda A, Miyazawa T, Suda M, Miura M, Ogawa Y, Nakao K: Significance of C-type natriuretic peptide (CNP) in endochondral ossification: analysis of CNP knockout mice. J Bone Miner Metab 2002, 20:33I-6.

12. Mericq V, Uyeda JA, Barnes KM, De Luca F, Baron J: Regulation of fetal rat bone growth by C-type natriuretic peptide and cGMP. Pediatr Res 2000, 47:189-93.

13. Yasoda A, Ogawa Y, Suda M, Tamura N, Mori K, Sakuma Y, Chusho H, Shiota K, Tanaka K, Nakao K: Natriuretic peptide regulation of endochondral ossification. Evidence for possible roles of the C-type natriuretic peptide/guanylyl cyclase-B pathway. J Biol Chem 1998, 273: I 1695-700.

14. Bartels CF, Bukulmez H, Padayatti P, Rhee DK, van Ravenswaaij-Arts C, Pauli RM, Mundlos S, Chitayat D, Shih LY, Al-Gazali LI, et al:: Mutations in the transmembrane natriuretic peptide receptor NPR-B impair skeletal growth and cause acromesomelic dysplasia, type Maroteaux. Am J Hum Genet 2004, 75:27-34.

15. Baxter GF: The natriuretic peptidesAn introduction. Basic Res Cardiol 2004, 99:7I-5.

16. Potter LR, Abbey-Hosch S, Dickey DM: Natriuretic Peptides, Their Receptors and cGMP-dependent Signaling Functions. Endocr Rev 2005.

17. Schulz S: C-type natriuretic peptide and guanylyl cyclase B receptor. Peptides 2005, 26:1024-34.

18. Cea LB: Natriuretic peptide family: new aspects. Curr Med Chem Cardiovasc Hematol Agents 2005, 3:87-98.

19. Pfeifer A, Aszodi A, Seidler U, Ruth P, Hofmann F, Fassler R: Intestinal secretory defects and dwarfism in mice lacking cGMPdependent protein kinase II. Science 1996, 274:2082-6.

20. Miyazawa T, Ogawa Y, Chusho H, Yasoda A, Tamura N, Komatsu Y, Pfeifer A, Hofmann F, Nakao K: Cyclic GMP-dependent protein kinase II plays a critical role in C-type natriuretic peptide- 
mediated endochondral ossification. Endocrinology 2002, | 43:3604-10.

21. Yasoda A, Komatsu Y, Chusho H, Miyazawa T, Ozasa A, Miura M, Kurihara T, Rogi T, Tanaka S, Suda M, et al.: Overexpression of CNP in chondrocytes rescues achondroplasia through a MAPK-dependent pathway. Nat Med 2004, 10:80-86.

22. Krejci P, Masri B, Fontaine V, Mekikian PB, Weis M, Prats H, Wilcox WR: Interaction of fibroblast growth factor and $C$-natriuretic peptide signaling in regulation of chondrocyte proliferation and extracellular matrix homeostasis. J Cell Sci 2005, I I 8:5089-5 I00.

23. Ozasa A, Komatsu $Y$, Yasoda A, Miura M, Sakuma $Y$, Nakatsuru $Y$, Arai $\mathrm{H}$, Itoh N, Nakao K: Complementary antagonistic actions between C-type natriuretic peptide and the MAPK pathway through FGFR-3 in ATDC5 cells. Bone 2005, 36:1056-64.

24. Pearson G, Robinson F, Beers Gibson T, Xu BE, Karandikar M, Berman K, Cobb MH: Mitogen-activated protein (MAP) kinase pathways: regulation and physiological functions. Endocr Rev 200I, 22: I53-83.

25. Cobb MH: MAP kinase pathways. Prog Biophys Mol Biol 1999 $7 I: 479-500$

26. Murakami S, Balmes G, McKinney S, Zhang Z, Givol D, de Crombrugghe $B$ : Constitutive activation of MEKI in chondrocytes causes Stat I-independent achondroplasia-like dwarfism and rescues the Fgfr3-deficient mouse phenotype. Genes Dev 2004, 18:290-305.

27. Zhang R, Murakami S, Coustry F, Wang Y, de Crombrugghe B: Constitutive activation of MKK6 in chondrocytes of transgenic mice inhibits proliferation and delays endochondral bone formation. PNAS 2006, 103:365-370.

28. James CG, Appleton CTG, Ulcii V, Underhill TM, Beier F: Microarray Analyses of Gene Expression during Chondrocyte Differentiation Identifies Novel Regulators of Hypertrophy. Mol Biol Cell 2005, 16:5316-5333.

29. Zhang X, Ziran N, Goater JJ, Schwarz EM, Puzas JE, Rosier RN, Zuscik $M$, Drissi H, O'Keefe RJ: Primary murine limb bud mesenchymal cells in long-term culture complete chondrocyte differentiation: TGF-beta delays hypertrophy and PGE2 inhibits terminal differentiation. Bone 2004, 34:809-17.

30. Zhang X, Schwarz EM, Young DA, Puzas JE, Rosier RN, O'Keefe RJ: Cyclooxygenase-2 regulates mesenchymal cell differentiation into the osteoblast lineage and is critically involved in bone repair. J Clin Invest 2002, I09: I 405-I5.

31. Li TF, Zuscik MJ, lonescu AM, Zhang X, Rosier RN, Schwarz EM, Drissi $H$, O'Keefe RJ: PGE2 inhibits chondrocyte differentiation through PKA and PKC signaling. Exp Cell Res 2004, 300:159-69.

32. Xing L, Schwarz EM, Boyce BF: Osteoclast precursors, RANKL RANK, and immunology. Immunol Rev 2005, 208:19-29.

33. Kostenuik PJ: Osteoprotegerin and RANKL regulate bone resorption, density, geometry and strength. Curr Opin Pharma$\mathrm{col}$ 2005, 5:6|8-25.

34. Kanehisa M: The KEGG database. Novartis Found Symp 2002, 247:91-101. discussion I0I-3, I19-28, 244-52.

35. Kishimoto K, Kitazawa R, Kurosaka M, Maeda S, Kitazawa S: Expression profile of genes related to osteoclastogenesis in mouse growth plate and articular cartilage. Histochem Cell Biol 2005: I-10.

36. Silvestrini G, Ballanti P, Patacchioli F, Leopizzi M, Gualtieri N, Monnazzi P, Tremante E, Sardella D, Bonucci E: Detection of osteoprotegerin (OPG) and its ligand (RANKL) mRNA and protein in femur and tibia of the rat. J Mol Histol 2005, 36:59-67.

37. Kartsogiannis V, Zhou H, Horwood NJ, Thomas RJ, Hards DK, Quinn JM, Niforas P, Ng KW, Martin TJ, Gillespie MT: Localization of RANKL (receptor activator of NF kappa B ligand) mRNA and protein in skeletal and extraskeletal tissues. Bone 1999 25:525-34

38. Zhen X, Wei L, Wu Q, Zhang Y, Chen Q: Mitogen-activated protein kinase $\mathrm{p} 38$ mediates regulation of chondrocyte differentiation by parathyroid hormone. J Biol Chem 2000, 275: I5.

39. Wang G, Beier F: Racl/Cdc42 and RhoA GTPases antagonistically regulate chondrocyte proliferation, hypertrophy, and apoptosis. J Bone Miner Res 2005, 20: 1022-31.

40. Stanton LA, Sabari S, Sampaio AV, Underhill TM, Beier F: p38 MAP kinase signalling is required for hypertrophic chondrocyte differentiation. Biochem / 2004, 378:53-62.
41. Stanton LA, Beier F: Inhibition of p38 MAPK signaling in chondrocyte cultures results in enhanced osteogenic differentiation of perichondral cells. Exp Cell Res 2007, 3 I 3: | 46-55.

42. Lasa M, Mahtani KR, Finch A, Brewer G, Saklatvala J, Clark AR: Regulation of cyclooxygenase 2 mRNA stability by the mitogenactivated protein kinase p38 signaling cascade. Mol Cell Biol 2000, 20:4265-74

43. Dean JL, Brook M, Clark AR, Saklatvala J: p38 mitogen-activated protein kinase regulates cyclooxygenase-2 mRNA stability and transcription in lipopolysaccharide-treated human monocytes. J Biol Chem 1999, 274:264-9.

44. Ridley SH, Dean JL, Sarsfield SJ, Brook M, Clark AR, Saklatvala J: A p38 MAP kinase inhibitor regulates stability of interleukin- Iinduced cyclooxygenase-2 mRNA. FEBS Lett 1998, 439:75-80.

45. Shimoaka T, Ogasawara T, Yonamine A, Chikazu D, Kawano H, Nakamura K, Itoh N, Kawaguchi $\mathrm{H}$ : Regulation of osteoblast, chondrocyte, and osteoclast functions by fibroblast growth factor (FGF)- 18 in comparison with FGF-2 and FGF-I0. J Biol Chem 2002, 277:7493-500.

46. Raucci A, Laplantine E, Mansukhani A, Basilico C: Activation of the ERKI/2 and p38 Mitogen-activated Protein Kinase Pathways Mediates Fibroblast Growth Factor-induced Growth Arrest of Chondrocytes. J Biol Chem 2004, 279: I747-1756.

47. Appleton CT, James CG, Beier F: Regulator of G-protein signaling (RGS) proteins differentially control chondrocyte differentiation. J Cell Physiol 2006.

48. James CG, Woods A, Underhill TM, Beier F: The transcription factor ATF3 is upregulated during chondrocyte differentiation and represses cyclin DI and A gene transcription. BMC Mol Biol 2006, 7:30

49. Chikuda $H$, Kugimiya $F$, Hoshi $K$, Ikeda $T$, Ogasawara T, Shimoaka $T$, Kawano H, Kamekura S, Tsuchida A, Yokoi N, et al.: Cyclic GMP. dependent protein kinase II is a molecular switch from proliferation to hypertrophic differentiation of chondrocytes. Genes Dev 2004, 18:2418-2429.

50. Luyten FP: Cartilage-derived morphogenetic protein-I. Int Biochem Cell Biol 1997, 29:124I-4.

5I. Francis-West PH, Abdelfattah A, Chen P, Allen C, Parish J, Ladher R, Allen S, MacPherson S, Luyten FP, Archer CW: Mechanisms of GDF-5 action during skeletal development. Development 1999, 126: 1305-15

52. Zuniga A, Michos O, Spitz F, Haramis A-PG, Panman L, Galli A, Vintersten K, Klasen C, Mansfield W, Kuc S, et al.: Mouse limb deformity mutations disrupt a global control region within the large regulatory landscape required for Gremlin expression. Genes Dev 2004, 18:1553-1564

53. Khokha MK, Hsu D, Brunet LJ, Dionne MS, Harland RM: Gremlin is the BMP antagonist required for maintenance of Shh and Fgf signals during limb patterning. Nat Genet 2003, 34:303-7.

54. Capdevila J, Tsukui T, Rodriquez Esteban C, Zappavigna V, Izpisua Belmonte JC: Control of vertebrate limb outgrowth by the proximal factor Meis2 and distal antagonism of BMPs by Gremlin. Mol Cell 1999, 4:839-49.

55. Merino R, Rodriguez-Leon J, Macias D, Ganan Y, Economides AN, Hurle JM: The BMP antagonist Gremlin regulates outgrowth, chondrogenesis and programmed cell death in the developing limb. Development 1999, 126:5515-22.

56. Zuniga A, Haramis AP, McMahon AP, Zeller R: Signal relay by BMP antagonism controls the SHH/FGF4 feedback loop in vertebrate limb buds. Nature 1999, 401:598-602

57. Pangas SA, Jorgez C], Matzuk MM: Growth differentiation factor 9 regulates expression of the bone morphogenetic protein antagonist gremlin. J Biol Chem 2004, 279:3228I-6.

58. Ahn J, Serrano de la Pena L, Shore EM, Kaplan FS: Paresis of a bone morphogenetic protein-antagonist response in a genetic disorder of heterotopic skeletogenesis. J Bone Joint Surg Am 2003 , 85-A:667-74.

59. Pereira RC, Economides AN, Canalis E: Bone morphogenetic proteins induce gremlin, a protein that limits their activity in osteoblasts. Endocrinology 2000, I 4I:4558-63.

60. Serra R, Karaplis A, Sohn P: Parathyroid hormone-related peptide (PTHrP)-dependent and - independent effects of transforming growth factor beta (TGF-beta) on endochondral bone formation. J Cell Biol 1999, I 45:783-94. 
61. Alvarez J, Horton J, Sohn P, Serra R: The perichondrium plays an important role in mediating the effects of TGF-betal on endochondral bone formation. Dev Dyn 200I, 22 I:3 I I-2I.

62. Colnot C, Lu C, Hu D, Helms JA: Distinguishing the contributions of the perichondrium, cartilage, and vascular endothelium to skeletal development. Dev Biol 2004, 269:55-69.

63. Babelomics [http://babelomics.bioinfo.cipf.es/index.html]

64. Woods A, Wang G, Beier F: RhoA/ROCK signaling regulates Sox9 expression and actin organization during chondrogenesis. J Biol Chem 2005, 280: I 1626-34. 